Article

\title{
Scalable Carbon Nanotube/Platinum Nanoparticle Composite Inks from Salt Templates for Oxygen Reduction Reaction Electrocatalysis for PEM Fuel Cells
}

\author{
Enoch A. Nagelli ${ }^{1,2, *} \mathbb{0}$, F. John Burpo ${ }^{1,2, *}$, Delaney A. Marbach ${ }^{1}$, Aaron N. Romero ${ }^{1}$, \\ Daniel J. Rabbia ${ }^{1}$, Hugh W. Mahr ${ }^{1}$, Mark H. Jaskot ${ }^{1}$, Asia N. Murray ${ }^{1}$ and Deryn D. Chu ${ }^{3}$ \\ 1 Department of Chemistry \& Life Science United States Military Academy, West Point, NY 10996, USA; \\ delaney.marbach@westpoint.edu (D.A.M.); aaron.romero@westpoint.edu (A.N.R.); \\ daniel.rabbia@westpoint.edu (D.J.R.); hugh.mahr@westpoint.edu (H.W.M.); \\ mark.jaskot@westpoint.edu (M.H.J.); asia.murray@westpoint.edu (A.N.M.) \\ 2 Photonics Research Center, United States Military Academy, West Point, NY 10996, USA \\ 3 Sensors \& Electron Devices Directorate, U.S. Army Research Laboratory, 2800 Powder Mill Road, \\ Adelphi, MD 20783, USA; deryn.d.chu.civ@mail.mil \\ * Correspondence: enoch.nagelli@westpoint.edu (E.A.N.); john.burpo@westpoint.edu (F.J.B.); \\ Tel.: +1-845-938-3904 (E.A.N.)
}

Received: 14 September 2020; Accepted: 21 October 2020; Published: 26 October 2020

\begin{abstract}
Platinum nanoparticles supported on multi-walled carbon nanotubes (CNTs) were synthesized by the chemical reduction of Magnus's salt templates formed by the electrostatic stacking of oppositely charged platinum coordinated ions. The Magnus's salt templated synthesis of platinum macrotubes, previously demonstrated, results in sidewalls made up of individual textured nanoparticles $100 \mathrm{~nm}$ in diameter and comprised of $5 \mathrm{~nm}$ diameter fibrils. Here we demonstrate a new platform method that utilizes the individual nanoparticles that make up the platinum macrotubes formed from salt templates and subsequently disperse them through a CNT network by ultrasonication to develop an electrocatalyst nanocomposite for the oxygen reduction reaction (ORR) critical for the development of proton exchange membrane (PEM) fuel cell applications. The structural morphology and composition of the nanocomposite catalysts was characterized using scanning electron microscopy (SEM), X-ray diffractometry (XRD), and Raman spectroscopy to confirm the presence of platinum nanoparticles throughout the CNT network of the nanocomposite. The electrocatalytic activity of the nanocomposite inks was verified with cyclic voltammetry (CV), electrochemical impedance spectroscopy (EIS), and linear sweep voltammetry (LSV) for ORR. Furthermore, this all aqueous-based and scalable approach for the synthesis and dispersion of platinum nanoparticles with CNTs can lead to a new formulation process for the production of electrocatalytic nanocomposite inks for PEM fuel cells using the nanoparticles that form within salt templates after chemical reduction.
\end{abstract}

Keywords: nanocomposite ink; carbon nanotube; platinum nanoparticles; electrocatalysis; fuel cells

\section{Introduction}

Proton exchange membrane (PEM) fuel cells are an environmentally-friendly and cost-effective renewable energy source [1]. The limiting factor for extensive implementation of PEM fuel cells is its dependence on expensive noble metals such as platinum-based electrocatalyst inks used in the oxygen reduction reaction (ORR) at the cathode [2,3]. Extensive research has gone into developing a scalable, high performance, and cost-effective catalyst for ORR [4-7]. Optimizing the catalyst ink 
formulation for brush painting, spray painting, sputter deposition, or inkjet printing of membrane electrode assemblies (MEAs) is important to the performance of PEM fuel cells [8,9]. Carbon black is often used as a conductive support for Pt-based electrocatalyst inks due to its high surface area and high conductivity [10-12]. Catalyst supports require properties, such as high surface area and high electronic conductivity, to maintain high catalytic activity [13]. While platinum remains an efficient electrocatalyst [14], carbon black degrades over time decreasing durability and increasing the cost of the catalyst due to the need for regeneration [15]. Possible replacements for carbon black are carbon tubule membranes [16], ordered porous carbon [17], graphite nanofibers [18], films of C60 clusters [19], hard carbon spherules [20], and carbon nanotubes [21]. In general, incorporating a high surface area electrocatalyst layer to serve as electrodes in PEM fuel cells increases performance and durability [22]. It also helps overcome the sluggish kinetics for the reduction of oxygen at the cathode [23].

Recent efforts have demonstrated various carbon-based binders in composite inks to include carbon-coating shells [24,25], graphene [26,27], mesoporous carbon [28], colloid-imprinted carbon supports [29], and single-walled CNTs [30]. However, the integration of carbon binders with Pt to manufacture nanocomposite inks from all aqueous processes is still a challenge, particularly with nanoparticle agglomeration in extended performance cycling [31]. Many efforts focus on chemical functionalization of CNTs to increase effective reaction sites for the integration of metal nanoparticles [10]. To replace carbon black, we utilize pristine CNTs-manufactured in industry without any surface modification or functionalization-to be combined with $\mathrm{Pt}$ nanoparticles from a chemically reduced salt template and dispersed in an aqueous solution. CNTs are insoluble in most solvents thus $\mathrm{Pt}$ nanoparticles in general do not easily bind [32]; however, catalyst inks contain an ionomer binder, Nafion $^{\mathrm{TM}}$, to aid in nanoparticle dispersion and proton transport. The synthesized nanocomposite ink is an all aqueous mixture of Nafion ${ }^{\mathrm{TM}}$, CNTs, and platinum nanoparticles, which act as a carbon-supported MEA electrocatalyst [9]. The high surface area-to-volume ratio of platinum nanoparticles allows for greater electrochemical active surface area through the dispersed high aspect ratio CNT network of the cathode [33]. The synergistic properties of CNTs and platinum nanoparticles (PtNP/CNT) facilitate high activity, chemical stability, mechanical strength and modulus, and integrability [3,34]. Moreover, this resulting nanocomposite suspension decreases the size of agglomerates that can form during the casting process. Electrodes with large catalyst agglomerates due to insufficient dispersion have low mass specific performance in comparison to well dispersed catalysts [22]. The formulation of a catalyst ink from aqueous solutions with the rapid formation of uniformly dispersed catalyst nanoparticles from the reduction of salt templates enables a composite ink structure with surface accessible active sites for scalable fuel cell electrode fabrication [35].

Here we demonstrate a scalable method to use the aqueous Magnus's salt structure as a sacrificial template [36-40] to create nanocomposite inks with platinum nanostructures dispersed in a CNT network to maximize the catalytically active surface area. This entirely aqueous scalable approach to an electrocatalyst ink uses the primary platinum nanoparticles of the sacrificial Magnus's salt templates to disperse with CNTs. The ultrasonication of the resulting Pt macrotubes after chemical reduction of the salt templates is a unique and rapid way to form nanocomposites of Pt nanoparticles and CNTs without the need of surfactants or capping agents. The chemically reduced Magnus's salts result in Pt macrotubes that are comprised of primary nanoparticles [36-40]. This technique utilizes ultrasonication to break apart the macrostructure of the $\mathrm{Pt}$ macrotubes and disperse the high surface area primary $\mathrm{Pt}$ nanoparticles throughout the CNTs to form an electrocatalyst nanocomposite. Utilizing the chemical reduction and dispersion of noble metal salt templates with carbon nanomaterials such as CNTs, can lead to improved composite electrode designs for fuel cell electrocatalysis. The PtNP/CNT nanocomposites provide high surface area for high catalytic activity for ORR [19]. Material characterization was performed with scanning electron microscopy (SEM), X-ray diffractometry (XRD), and Raman spectroscopy. Electrochemical characterization and performance were conducted on the resulting $\mathrm{PtNP} / \mathrm{CNT}$ nanocomposite inks with electrochemical impedance spectroscopy, cyclic voltammetry, and linear sweep voltammetry in $0.5 \mathrm{M} \mathrm{H}_{2} \mathrm{SO}_{4}$ electrolyte. 


\section{Materials and Methods}

\subsection{Pt Nanoparticle/CNT Nanocomposite Ink Synthesis}

To form Magnus's salt needle templates, $100 \mathrm{mM}$ and $25 \mathrm{mM}$ salt solutions of $\mathrm{Na}_{2} \mathrm{PtCl}_{4} \cdot \mathrm{xH}_{2} \mathrm{O}$ (Sigma Aldrich, St. Louis, USA) and $\mathrm{Pt}\left(\mathrm{NH}_{3}\right)_{4} \mathrm{Cl}_{2} \cdot \mathrm{H}_{2} \mathrm{O}$ (Sigma Aldrich, St. Louis, USA) were prepared. Upon addition of equal volume and molarity solutions, $\left[\mathrm{PtCl}_{4}\right]^{2-}$ and $\left[\mathrm{Pt}\left(\mathrm{NH}_{3}\right)_{4}\right]^{2+}$ ions rapidly self-assemble linearly into high aspect ratio Magnus's salt needles [36,41,42]. The Magnus's salt crystals prepared with $100 \mathrm{mM}$ and $25 \mathrm{mM}$ platinum salt solutions were each reduced in $0.1 \mathrm{M}$ sodium borohydride, $\mathrm{NaBH}_{4}$, at 1:50 (v/v) platinum salt to reducing agent solution to form porous macrotubes [36]. The reduced platinum macrotubes were rinsed with deionized water and centrifuged (Thermo Scientific Pico 17 17,000× g, Microcentrifuge, 120 V 60 Hz, Waltham, MA, USA) at 14,800 rpm for $20 \mathrm{~min}$ in a 1:1 deionized water:ethanol solvent several times. Platinum macrotubes were collected and dried overnight at $60{ }^{\circ} \mathrm{C}$ in an open-air oven.

In order to prepare the composite inks, the platinum macrotubes were mixed with varying amounts of carbon nanotubes. Composites were prepared by adding the dry Pt macrotubes to varying weight wt \% (relative to the mass of $\mathrm{Pt}$ ) of pristine 8-15 nm diameter multi-walled CNTs (Cheap Tubes Inc., Grafton, VT, USA), $30 \mu \mathrm{L}$ of $5 \mathrm{wt} \%$ Nafion $^{\mathrm{TM}}$ solution, $1 \mathrm{~mL}$ of isopropyl alcohol (IPA), and $12 \mathrm{~mL}$ deionized (DI) water were added together to make an ink solution. Approximately $0.056 \mathrm{~g}$ of $25 \mathrm{mM}$ porous platinum macrotubes were combined with $10 \mathrm{wt} \%$ carbon nanotubes, $30 \mu \mathrm{L} \mathrm{Nafion}{ }^{\mathrm{TM}}, 1 \mathrm{~mL}$ of isopropyl alcohol (IPA), and $12 \mathrm{~mL}$ deionized water. This process was repeated with $20 \mathrm{wt} \%$ and $30 \mathrm{wt} \%$ carbon nanotubes with respect to the mass of platinum macrotubes. In addition, approximately $0.054 \mathrm{~g}$ of $100 \mathrm{mM}$ platinum macrotubes were used to create $10 \mathrm{wt} \%, 20 \mathrm{wt} \%$, and $30 \mathrm{wt} \%$ carbon nanotube inks. All of the resulting ink solutions were placed into an ultrasonic bath (VWR Ultrasonic Cleaners, Radnor, PA, USA) filled with water $\left(20^{\circ} \mathrm{C}\right)$ and sonicated $(35 \mathrm{kHz}, 160$ Watt) for $45 \mathrm{~min}$ and stored at room temperature to form PtNP/CNT nanocomposite inks. The catalytic performance of the PtNP/CNT inks were compared to a standard Pt Black ink (Pt/C) produced by mixing $7.2 \mathrm{mg}$ of Pt Black catalyst powder (Sigma Aldrich, St. Louis, MO, USA) with $10.8 \mathrm{mg}$ of graphite flakes (99\% carbon basis, Sigma Aldrich, St. Louis, MO, USA), $30 \mu \mathrm{L}$ of $5 \mathrm{wt} \%$ Nafion solution, $1 \mathrm{~mL}$ IPA, and $6 \mathrm{~mL}$ of DI water to make $40 \mathrm{wt} \% \mathrm{Pt} / \mathrm{C}$ ink $[8,9,43,44]$. The $\mathrm{Pt} / \mathrm{C}$ ink was placed in an ultrasonic bath filled with water $\left(20^{\circ} \mathrm{C}\right)$ and sonicated $(35 \mathrm{kHz}, 160$ Watt $)$ for $45 \mathrm{~min}$.

\subsection{Scanning Electron Microscopy (SEM)}

Scanning electron microscopy and energy dispersive $x$-ray spectroscopy were used to characterize the morphology and composition of the PtNP/CNT nanocomposites using a JEOL IT500HRLA SEM (JEOL USA, Peabody, MA, USA). A $20 \mathrm{kV}$ beam voltage was used for imaging. SEM image analysis was conducted using ImageJ [45,46].

\subsection{X-ray Diffractometry (XRD)}

X-ray diffractometry (XRD) spectra were collected using a Malvern Panalytical Empyrean diffractometer (Malvern Panalytical, Almelo, Netherlands) using $\mathrm{Cu} \mathrm{K}_{\alpha}$ radiation (1.54060 $\left.\mathrm{A}\right), 45 \mathrm{kV}$

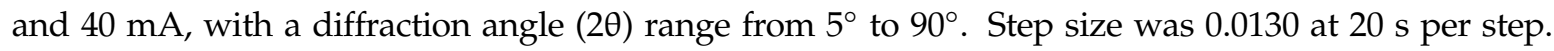
XRD spectra analysis was performed using High Score Plus software (Panalytical). Crystallite size (D) was calculated using the Debye-Scherrer formula, $D=K \lambda /(B \cos \theta)$, where a shape factor of $K=0.9$ was used. The remaining variables are full width at half maxima $(B)$, radiation wave length $(\lambda)$, and Bragg angle $(\theta)$.

\subsection{Raman Spectroscopy}

Raman Spectroscopy was performed on the PtNP/CNT composites using a Horiba XploRA Plus Raman Microscope spectrometer (XploRA, HORIBA Scientific, France). A $532 \mathrm{~nm}$ excitation laser was focused on the sample using a 50× magnification, $0.55 \mathrm{NA}, 20 \mathrm{~mm}$ long working distance objective lens. 


\subsection{Electrochemical Characterization}

A Bio-Logic VMP-3 potentiostat (Bio-Logic, Knoxville, TN, USA) was used to perform electrochemical impedence spectroscopy (EIS), cyclic voltammetry (CV), and linear sweep voltammetry (LSV) of the PtNP/CNT composite inks. PtNP/CNT composite inks were transferred onto a glassy carbon (GC) stationary working electrode (3 mm OD LowProfile E1B, Pine Research Instrumentation, Durham, NC USA) for all EIS and CV tests and a rotating disk electrode (RDE) for all LSV tests (5.0 mm disk OD E2M FastSpeed RDE, Pine Research Instrumentation, Durham, NC USA). The GC and RDE were polished with fine alumina slurry, rinsed with DI water, and dried at $60^{\circ} \mathrm{C}$ in an open-air oven. $100 \mu \mathrm{L}$ of each PtNP/CNT ink was drop casted onto an electrode and dried in a vacuum oven $\left(60{ }^{\circ} \mathrm{C}, 10 \mathrm{kPa}\right)$ for $1 \mathrm{~h}$ to gradually dry the ink suspension onto the GC electrode. All electrochemical tests were conducted with a $\mathrm{KCl}$ saturated $\mathrm{Ag} / \mathrm{AgCl}$ reference electrode (MF-2052 $3 \mathrm{M} \mathrm{NaCl}$ ), BASi, West Lafayette, IN, USA), a $6 \mathrm{~cm}$ long platinum wire counter-electrode (MW4130 Platinum Auxiliary Electrode, BASi, West Lafayette, IN, USA) in a three electrode cell configuration in $0.5 \mathrm{M} \mathrm{H}_{2} \mathrm{SO}_{4}$ electrolyte. All potential measurements in Volts $(\mathrm{V})$ vs an $\mathrm{Ag} / \mathrm{AgCl}$ reference electrode can be evaluated vs the standard hydrogen electrode (SHE) by adding $0.197 \mathrm{~V}$ to the measured potentials reported. EIS was performed at $0 \mathrm{~V}$ ( $\mathrm{vs} \mathrm{Ag/AgCl}$ ) with a $10 \mathrm{mV}$ sine wave and a frequency range of $500 \mathrm{kHz}$ to $0.1 \mathrm{~Hz}$ in $\mathrm{N}_{2}$ purged $0.5 \mathrm{M} \mathrm{H}_{2} \mathrm{SO}_{4}$ electrolyte. $\mathrm{CV}$ was performed with scan rates of 5, 10, 25, 50, 75 , and $100 \mathrm{mV} / \mathrm{s}$ in the potential range of -0.2 to $+1.2 \mathrm{~V}$ (vs. Ag/AgCl) in $\mathrm{N}_{2}$ purged $0.5 \mathrm{M} \mathrm{H}_{2} \mathrm{SO}_{4}$ electrolyte. LSV from +1.2 to $0 \mathrm{~V}$ (vs. Ag/AgCl) was performed at 300, 500, 700, 900, and 1100 rotations per minute in $\mathrm{O}_{2}$ purged $0.5 \mathrm{M} \mathrm{H}_{2} \mathrm{SO}_{4}$ electrolyte.

\section{Results and Discussion}

\subsection{Pt Nanoparticle/CNT Ink Sythesis Scheme}

As shown in the scheme in Figure 1a,b, Magnus's salt needle templates were prepared by adding salt solutions with oppositely charged square planar platinum ions, and then chemically reduced with $\mathrm{NaBH}_{4}$ to form the Pt macrotubes with a square cross section [36]. After rinsing and drying, the platinum macrotubes were then combined with carbon nanotubes to form a composite as shown in Figure 1c. To break the macrotubes apart and to disperse the Pt nanoparticles comprised within, the composite inks were sonicated for $45 \mathrm{~min}$ each and stored at room temperature to achieve the final $\mathrm{Pt} / \mathrm{CNT}$ nanocomposite ink (Figure 1d,e).

(a)

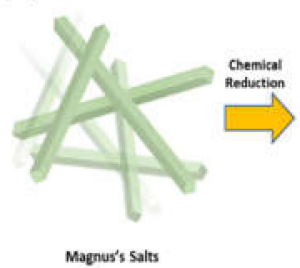

(b)

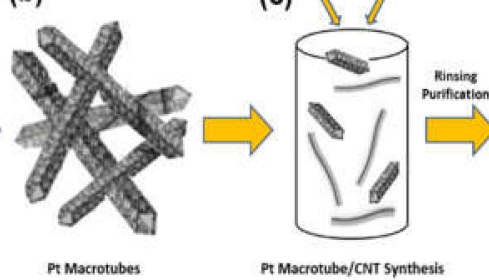

(d)

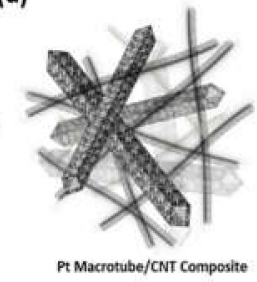

(e)

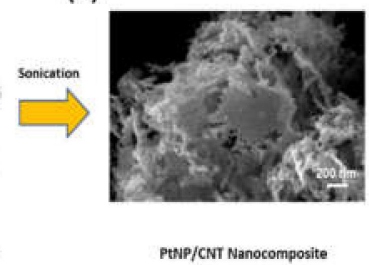

Figure 1. PtNP/carbon nanotube (CNT) nanocomposite synthesis scheme. $(\mathbf{a}, \mathbf{b})$ Chemical reduction of Magnus's salt crystals to form Pt macrotubes. (c) Addition of Pt macrotubes and CNTs at various wt \% CNTs to form a Pt-CNT nanocomposite. (d,e) Rinsing, purification, and ultrasonication of Pt macrotube/CNT composite to break up the macrostructure to form dispersed Pt nanoparticles with a network of CNTs resulting in a PtNP/CNT Nanocomposite.

In Figure 1d, the CNTs formed a network for the Pt nanoparticles to disperse within. The dispersion of Pt macrotubes increases as the concentration of CNTs increases and the molarity of Pt increases. The aqueous-based approach results in the same synthesis and dispersion method for each ratio of $\mathrm{Pt}$ macrotubes and CNTs. The SEM image in Figure 1e shows the dispersion of Pt throughout the CNT 
network. This process develops a scalable, all aqueous, and facile approach to form an electrocatalyst nanocomposite for the oxygen reduction reaction (ORR).

\subsection{Structural Characterization of PtNP/CNT Nanocomposite}

\subsubsection{Scanning Electron Microscopy (SEM)}

$\mathrm{PtNP} / \mathrm{CNT}$ nanocomposites were analyzed with SEM to gain insight into the structure of the platinum nanoparticles dispersed in the CNT network. Figure $2 \mathrm{a}-\mathrm{i}$ shows the distribution of the $\mathrm{Pt}$ nanoparticle aggregates of varying size embedded with CNTs. The SEM images confirm the presence of fused and fragmented $\mathrm{Pt}$ nanoparticles broken apart from the sidewalls of the macrotubes from sonication. As shown in Figure $2 \mathrm{a}-\mathrm{f}$, the $25 \mathrm{mM}$ PtNP/CNT nanocomposites with $10 \mathrm{wt} \%$ and $20 \mathrm{wt} \%$ clearly show the presence of a connected network of CNTs with interfused platelets and spherical aggregates of primary nanoparticles and clusters of aggregates broken up from the $\mathrm{Pt}$ macrotube sidewalls. Moreover, Figure 2g-i show the SEM images of $100 \mathrm{mM}$ PtNP/CNT nanocomposites with 20 wt \% CNTs with aggregates of primary of Pt nanoparticles encapsulated with interconnected CNTs. Image analysis of the platinum particle sizes indicated a range of 4.4-18.3 nm and average diameter of $8.5 \pm 2.0 \mathrm{~nm}$ across all of the samples with no significant differences between platinum salt concentrations and CNT percentages (Figure S1, Table S1). As observed by SEM, the aggregates of Pt nanoparticles in the $25 \mathrm{mM} \mathrm{PtNP} / \mathrm{CNT}$ nanocomposites are larger than those of the $100 \mathrm{mM} \mathrm{PtNP/CNT}$ nanocomposites (Figures S2 and S3). This variation in size of the Pt nanoparticles in the 25 and 100 $\mathrm{mM} P t N P / C N T$ nanocomposites is due to the differences in the primary nanoparticles that make up the sidewall of the macrotube after chemical reduction of the Magnus's salt templates [36]. The high aspect ratio and van der Waals force within framework of the CNTs increases the surface area for contact and adhesion between the Pt nanoparticles and the sidewalls of the CNTs. This inter-fused $\mathrm{PtNP} / \mathrm{CNT}$ nanocomposite structure could help mitigate the challenge of degradation and removal of Pt particles from support materials thus leading to agglomeration effecting the catalytic activity and fuel cell performance [47-49]. In addition, the integration of the Pt nanoparticles fused into the CNT network can potentially minimize the corrosion of the carbon support and degrading the performance of PEM fuel cells [50,51].

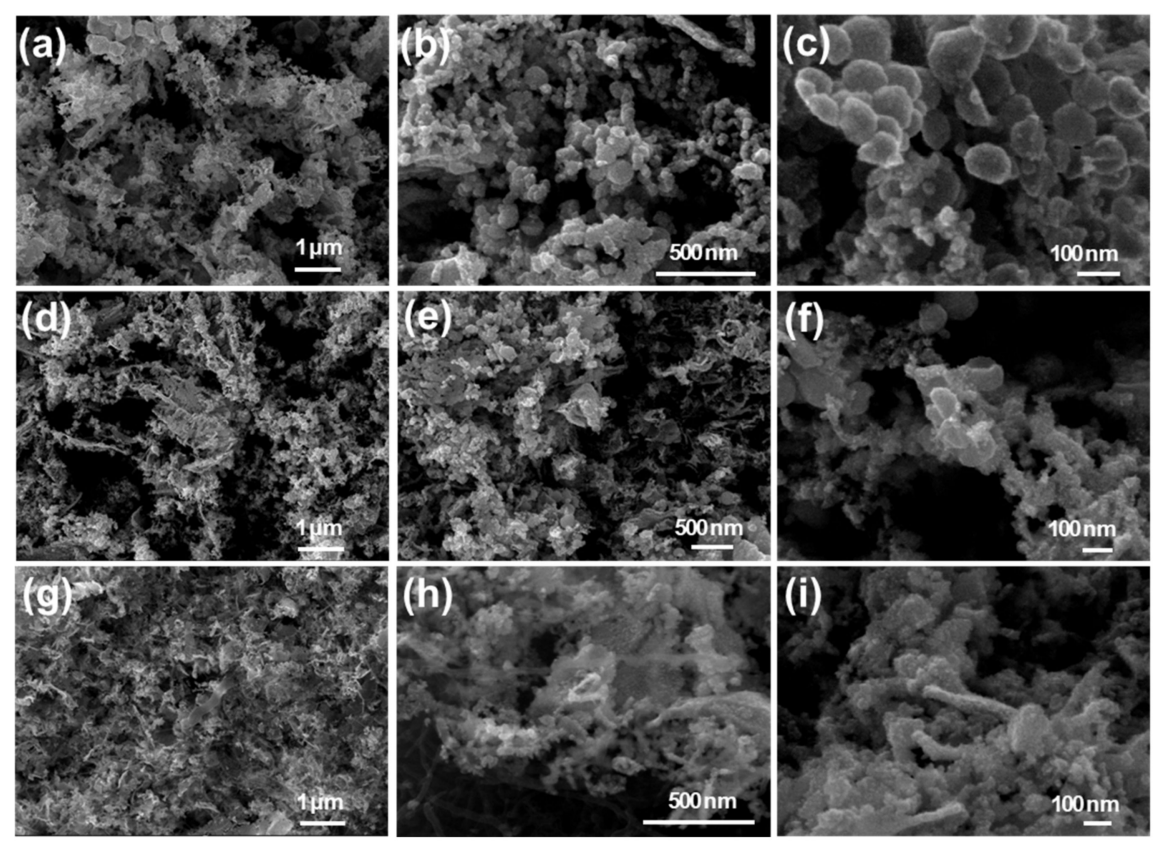

Figure 2. Scanning electron microscope images of (a-c) $25 \mathrm{mM} \mathrm{Pt}$ with $10 \mathrm{wt} \% \mathrm{CNTs},(\mathbf{d}-\mathbf{f}) 25 \mathrm{mM} \mathrm{Pt}$ with 20 wt \% CNTs, and (g-i) $100 \mathrm{mM}$ Pt with $20 \mathrm{wt} \%$ CNTs. 


\subsubsection{X-ray Diffractometry}

XRD spectra for the $25 \mathrm{mM}$ and $100 \mathrm{mM}$ with increasing wt \% CNTs shown in Figure 3 were indexed to Joint Committee on Powder Diffraction Standards (JCPDS) reference number 01-071-6560 for the fcc, Fm-3m space group, platinum phase, and 00-041-1487 for the graphitic carbon phase comprised of CNTs. For platinum, the peaks for Miller indices (111), (200), (220), (311), and (222) were observed at $39.84^{\circ}, 45.98^{\circ}, 67.70^{\circ}, 81.66^{\circ}$, and $85.95^{\circ}$, respectively. Using the Debeye-Scherrer equation to analyze the full-width-at-half-maximum (FWHM) of the platinum (111) peaks indicated crystallite sizes of $12 \mathrm{~nm}$ and $10 \mathrm{~nm}$ for the $25 \mathrm{mM} \mathrm{PtNP} / 30 \mathrm{wt} \% \mathrm{CNT}$ and $100 \mathrm{mM} \mathrm{PtNP} / 30 \mathrm{wt} \%$ CNT samples, respectively (Figure S4). The XRD-determined crystallite sizes closely correspond to the nanoparticle diameters determined from SEM image analysis. The broad, low-intensity graphitic carbon peak observed at approximately $25^{\circ}$ is convoluted with the glass substrate background signal but indicates the presence of CNTs in the nanocomposite ink mixture.

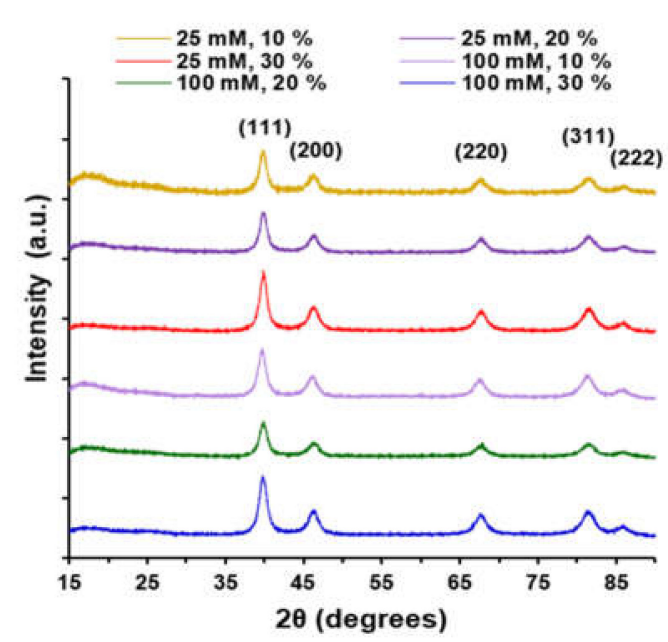

Figure 3. X-ray diffraction spectra for $25 \mathrm{mM} \mathrm{Pt}$ and $100 \mathrm{mM}$ Pt nanocomposites with increasing wt \% of CNTs: JCPDS reference platinum 01-071-6560 and carbon graphite 00-041-1487.

\subsubsection{Raman Spectroscopy}

Raman spectra in Figure 4 for the $25 \mathrm{mM}$ and $100 \mathrm{mM}$ PtNP/CNT nanocomposites show the typical spectrum of multi-walled CNTs with characteristic doublet peaks of the D-band and G-band at approximately $1330 \mathrm{~cm}^{-1}$ and $1550 \mathrm{~cm}^{-1}$, respectively. The D-band is a result of vibrations of $\mathrm{sp}^{3}$ bonded carbon atoms and dangling bonds, the G-band originates from the $\mathrm{sp}^{2}$ bonded carbon atoms within the structure of the CNTs, and the third prominent 2D-band arises from the second order electron-phonon intensity. The relative height of each peak determines the level of disorder within the graphitic CNT structure [52-54]. As shown in Figure 4a,b, the Raman spectra of the PtNP/CNT composites show the D (1347 to $\left.1352 \mathrm{~cm}^{-1}\right), \mathrm{G}\left(1578\right.$ to $\left.1586 \mathrm{~cm}^{-1}\right)$, and 2D (2679 to $\left.2697 \mathrm{~cm}^{-1}\right)$ bands, respectively. The $\mathrm{I}_{\mathrm{D}} / \mathrm{I}_{\mathrm{G}}$ ratio for $25 \mathrm{mM}$ and $100 \mathrm{mM} \mathrm{PtNP} / \mathrm{CNT}$ composites decreased with increasing the amount of CNTs in the PtNP/CNT nanocomposite due to the increase in the degree of graphitization from the presence of a larger amount of CNTs with respect to the amount of platinum nanoparticles to interact and introduce structural defects along the CNT structure [52,53]. Figure 4a depicts the Raman spectrum with the $\mathrm{I}_{\mathrm{D}} / \mathrm{I}_{\mathrm{G}}$ ratios of $25 \mathrm{mM} / 20 \mathrm{wt} \%$ and $25 \mathrm{mM} / 30 \mathrm{wt} \% \mathrm{PtNP} / \mathrm{CNT}$ nanocomposites to be 1.2 and 1.1, respectively, whereas it is 2.7 for the $25 \mathrm{mM} / 10 \mathrm{wt} \%$. Moreover, Figure $4 \mathrm{~b}$ shows the Raman spectrum with the $\mathrm{I}_{\mathrm{D}} / \mathrm{I}_{\mathrm{G}}$ ratios of the $100 \mathrm{mM} \mathrm{Pt} / \mathrm{CNT}$ nanocomposites at $10 \mathrm{wt} \%, 20 \mathrm{wt} \%$, and $30 \mathrm{wt} \%$ were $2.7,1.3$, and 1.2, respectively. The $\mathrm{I}_{\mathrm{D}} / \mathrm{I}_{\mathrm{G}}$ ratio of both the $25 \mathrm{mM}$ and $100 \mathrm{mM}$ $\mathrm{PtNP} / \mathrm{CNT}$ nanocomposites with higher wt \% CNTs is closer in magnitude to that of the $\mathrm{I}_{\mathrm{D}} / \mathrm{I}_{\mathrm{G}}$ ratio of pristine CNTs of 1.45 (Figure S5). Both of the PtNP/CNT nanocomposites from $25 \mathrm{mM}$ and $100 \mathrm{mM}$ with $10 \mathrm{wt} \% \mathrm{CNTs}$ have the highest $\mathrm{I}_{\mathrm{D}} / \mathrm{I}_{\mathrm{G}}$ ratio of 2.7. This is an indication of the presence of a more 
fused nanocomposite structure with Pt nanoparticles directly interacting with $\mathrm{sp}^{2}$ hybridized structure of the CNTs interfering with the innate graphitic structure of CNTs as evidenced from the change of $\mathrm{I}_{\mathrm{D}} / \mathrm{I}_{\mathrm{G}}$ ratio (1.45) of pristine CNTs (Figure S5) [54]. The noise in the 25 and $100 \mathrm{mM}$ spectra towards higher than $1900 \mathrm{~cm}^{-1}$ Raman shift is attributed to defects in the electronic and vibrational structure related to disorder of the local nanotube lattice [55].
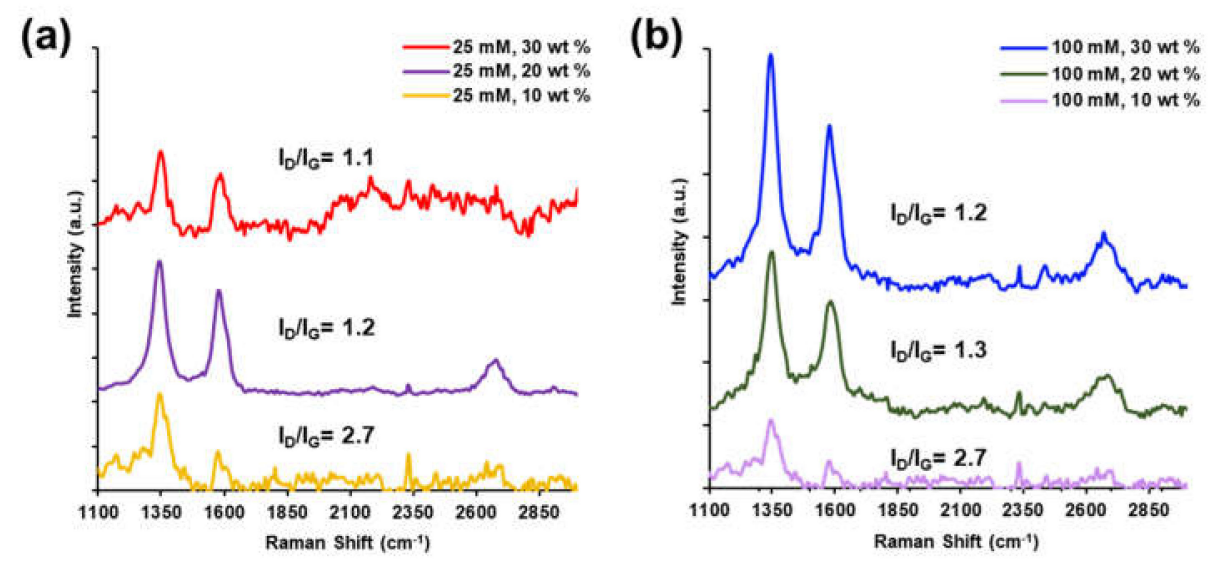

Figure 4. Raman spectroscopy of (a) $25 \mathrm{mM}$ Pt and (b) $100 \mathrm{mM}$ Pt with increasing wt $\%$ of CNTs.

\subsection{Electrochemical Characterization and Performance of the PtNP/CNT Nanocomposite Inks}

\subsubsection{Electrochemical Impedance Spectroscopy}

Electrochemical impedance spectroscopy was performed in $0.5 \mathrm{M} \mathrm{H}_{2} \mathrm{SO}_{4}$ in a frequency range of $500 \mathrm{kHz}$ to $0.1 \mathrm{~Hz}$, with the resulting Nyquist plots shown in Figure 5a,c. The 25 and $100 \mathrm{mM} \mathrm{PtNP/CNT}$ nanocomposites exhibit a characteristic porous electrode response with an arch in the high frequency region accompanied by a greater than $45^{\circ}$ slope at low frequencies [56,57]. The Warburg impedance in the low frequency region of the Nyquist plots is a straight line with a slope larger than $45^{\circ}$ associated with the mass transport resistance for the semi-infinite diffusion of electrolyte ions through PtNP/CNT nanocomposite [56,57]. However, as shown in both of the insets of Figure 5a,c, the high frequency region shows an inconspicuous arch with a nearly vertical line signifying a low charge transfer resistance for electrolyte diffusion into the porous PtNP/CNT nanocomposite ink network [56]. The high frequency resistance (HFR) intercept with the real ( $Z^{\prime}$ ) axis includes the total ohmic resistance, the ionic solution resistance, and the charge transfer resistance at the electrolyte interface [58]. The $25 \mathrm{mM}$ $\mathrm{PtNP} / 20 \mathrm{wt} \% \mathrm{CNT}$ and $100 \mathrm{mM} \mathrm{PtNP} / 10 \mathrm{wt} \% \mathrm{CNT}$ composite inks have the lowest HFR and thus low ionic resistance to electrolyte transport and lower electronic resistance through the nanocomposite structure. The ohmic area-specific resistance $\left(\mathrm{ASR}_{\mathrm{ohmic}}\right)$ of the composite inks was calculated from the HFR intercepts from the Nyquist plots [59]. As shown in Table 1, the ASR ${ }_{\text {ohmic }}$ of the $25 \mathrm{mM}$ PtNP inks with $20 \mathrm{wt} \%$ CNTs and the $100 \mathrm{mM}$ PtNP with $10 \mathrm{wt} \%$ CNTs were the lowest which is an indication of enhanced ionic conductivity through the composite ink structure.

Moreover, areal capacitances of the inks were determined from the complete range of frequencies of the Nyquist plot using the relation,

$$
\mathrm{C}_{\mathrm{a}}=1 /\left(2 \pi \mathrm{fZ} \mathrm{Z}^{\prime \prime} \mathrm{A}\right)
$$

where $\mathrm{f}$ is the frequency, $\mathrm{Z}$ " is the imaginary component of impedance, and $A$ is the geometric area of the PtNP/CNT on the GC electrode [60,61]. Areal capacitance as a function of frequency for the $25 \mathrm{mM}$ PtNP/CNT composite ink is plotted in Figure $5 \mathrm{~b}$ and for the $100 \mathrm{mM}$ PtNP/CNT composite ink in Figure $5 \mathrm{~d}$. At low frequencies, the $C_{a}$ of the $25 \mathrm{mM} \mathrm{PtNP} / \mathrm{CNT}$ composite ink was inversely proportional to the amount of CNTs. As shown in the inset of Figure $5 \mathrm{~d}$, at $0.7 \mathrm{~Hz}$, the $\mathrm{C}_{\mathrm{a}}$ of $25 \mathrm{mM}$ PtNP/CNT composite inks was $29 \mathrm{mF} / \mathrm{cm}^{2}$ with 10 wt $\%$ CNTs, $23 \mathrm{mF} / \mathrm{cm}^{2}$ with 20 wt \% CNTs, 
and $15 \mathrm{mF} / \mathrm{cm}^{2}$ with $30 \mathrm{wt} \%$ CNTs. The $\mathrm{C}_{\mathrm{a}}$ for $100 \mathrm{mM}$ PtNP and $10 \mathrm{wt} \% \mathrm{CNT}$ composite ink was the largest at $39 \mathrm{mF} / \mathrm{cm}^{2}$ but increasing the wt \% of CNTs to combine with $100 \mathrm{mM} \mathrm{PtNP}$ lowered the $\mathrm{C}_{\mathrm{a}}$ of the composite inks (Figure 5d). Moreover, increasing the mass of CNTs can lead to a loss of an open networks from the presence of more entanglements in CNTs effecting the overall surface area available for electrolyte transport through the composite ink thus lowering the capacitance.
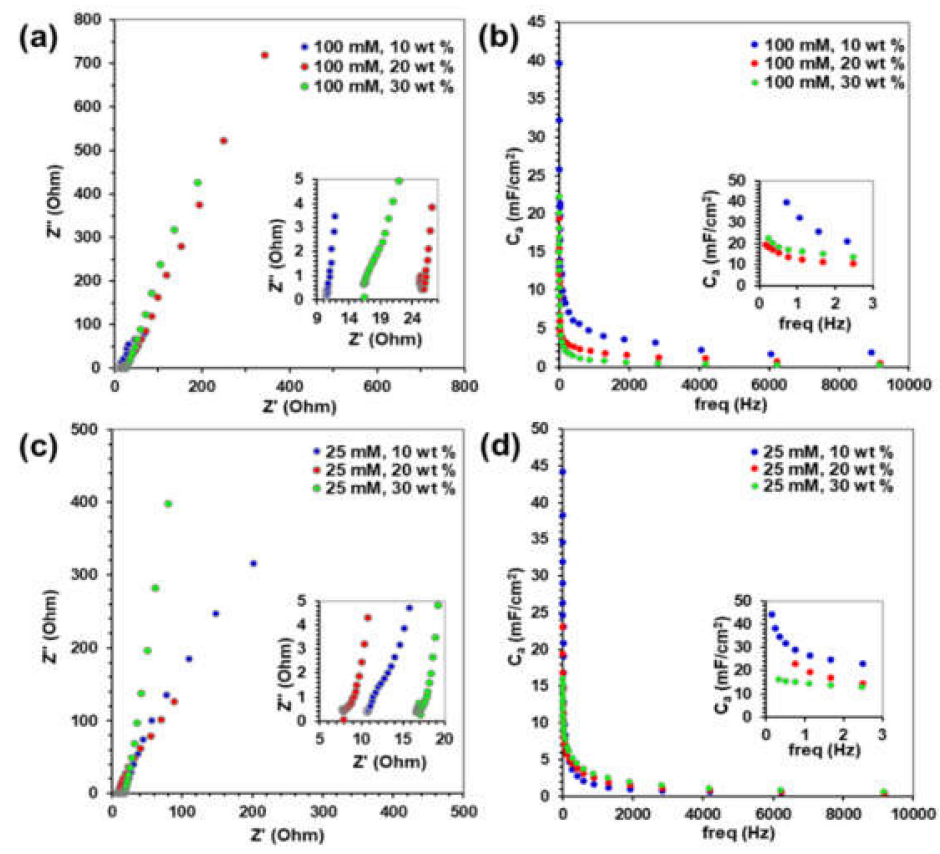

Figure 5. Electrochemical Impedance Spectroscopy. Nyquist Plots and Areal Capacitance vs Frequency of $(\mathbf{a}, \mathbf{b}) 100 \mathrm{mM}$ PtNP and (c,d) $25 \mathrm{mM}$ PtNP with increasing wt \% CNTs.

Table 1. Electrochemical Properties of PtNP/CNT Nanocomposite Inks.

\begin{tabular}{|c|c|c|c|c|c|c|c|c|}
\hline \multicolumn{2}{|c|}{ Composite Ink } & \multirow{2}{*}{$\begin{array}{c}\begin{array}{c}\mathbf{A S R}_{\text {ohmic }} \\
{\left[\mathbf{\Omega c m}^{2}\right]}\end{array} \\
0.761\end{array}$} & \multirow{2}{*}{$\begin{array}{c}\begin{array}{c}\mathrm{C}_{\mathrm{a}} \text { from EIS } \\
{\left[\mathrm{mF} / \mathrm{cm}^{2}\right]}\end{array} \\
29.0\end{array}$} & \multirow{2}{*}{$\begin{array}{c}\begin{array}{c}\mathrm{C}_{\mathrm{a}} \text { from } \mathrm{CV}^{2} \\
{\left[\mathrm{mF} / \mathrm{cm}^{2}\right]}\end{array} \\
17.7\end{array}$} & \multirow{2}{*}{$\begin{array}{c}\begin{array}{c}\text { QEDLC from CV } \\
{\left[\mathrm{mC} / \mathrm{cm}^{2}\right]}\end{array} \\
71.2\end{array}$} & \multirow{2}{*}{$\begin{array}{c}\operatorname{ECSA}_{\text {EDLC }}{ }^{4} \\
{\left[\mathrm{~cm}^{2} / \mathrm{mg}_{\mathrm{Pt}}\right]}\end{array}$} & \multirow{2}{*}{$\begin{array}{c}\frac{Q_{H} \text { from } \mathrm{CV}^{5}}{\left[\mathrm{mC} / \mathrm{cm}^{2}\right]} \\
8.77\end{array}$} & \multirow{2}{*}{$\begin{array}{c}\operatorname{ECSA}_{\mathbf{H}}{ }^{6} \\
{\left[\mathrm{~cm}^{2} / \mathrm{mg}_{\mathrm{Pt}}\right]}\end{array}$} \\
\hline E & $\begin{array}{c}10 \text { wt \% } \\
\text { CNT }\end{array}$ & & & & & & & \\
\hline$\frac{\vec{E}}{2}$ & $\begin{array}{c}20 w t \% \\
\text { CNT }\end{array}$ & 0.554 & 23.1 & 11.3 & 26.8 & 6.95 & 0.631 & 2.53 \\
\hline $\begin{array}{l}\sum_{\Xi} \\
\text { : } \\
\text { N }\end{array}$ & $\begin{array}{c}30 \text { wt } \% \\
\text { CNT }\end{array}$ & 1.21 & 14.9 & 2.14 & 26.6 & 6.90 & 3.33 & 0.863 \\
\hline \multirow{3}{*}{ 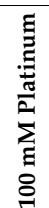 } & $\begin{array}{c}10 \mathrm{wt} \% \\
\text { CNT }\end{array}$ & 0.748 & 39.7 & 2.68 & 63.8 & 51.9 & 9.19 & 7.46 \\
\hline & $\begin{array}{c}20 w t \% \\
\text { CNT }\end{array}$ & 1.78 & 13.7 & 0.92 & 22.9 & 18.6 & 3.17 & 2.58 \\
\hline & $\begin{array}{c}30 \text { wt \% } \\
\text { CNT }\end{array}$ & 1.17 & 16.9 & 0.81 & 45.7 & 37.1 & 48.9 & 39.7 \\
\hline
\end{tabular}

${ }^{1} \mathrm{C}_{\mathrm{a}}$ from EIS at $0.7 \mathrm{~Hz} .{ }^{2} \mathrm{C}_{\mathrm{a}}$ from $\mathrm{CV}$ within the potential range of -0.2 to $1.2 \mathrm{~V}(\mathrm{vs} \mathrm{Ag} / \mathrm{AgCl})$ at $25 \mathrm{mV} / \mathrm{s}$.

${ }^{3} \mathrm{Q}_{\text {ELDC }}$ from CV within the potential range from -0.2 to $0 \mathrm{~V}(\mathrm{Ag} / \mathrm{AgCl})$ at $25 \mathrm{mV} / \mathrm{s}$ from the charge attributed to electrochemical double layer current (ELDC). ${ }^{4}$ Electrochemical active surface area (ECSA) from QELDC using the mass of the Pt macrotubes used in the ink synthesis and the average charge density is $210 \mu \mathrm{C} / \mathrm{cm}^{2}$ for hydrogen adsorption for polycrystalline Pt. ${ }^{5} \mathrm{Q}_{\mathrm{H}}$ from CV within the potential range from -0.2 to $0 \mathrm{~V}(\mathrm{Ag} / \mathrm{AgCl})$ at $25 \mathrm{mV} / \mathrm{s}$ from the charge attributed to the average coulombic charge from the electro-adsorption and desorption of hydrogen. ${ }^{6}$ ECSA from $\mathrm{Q}_{\mathrm{H}}$ using the mass of the Pt macrotubes used in the ink synthesis and the average charge density is $210 \mu \mathrm{C} / \mathrm{cm}^{2}$ for hydrogen adsorption for polycrystalline $\mathrm{Pt}$.

\subsubsection{Cyclic Voltammetry}

Cyclic voltammetry was performed in $\mathrm{N}_{2}$-purged $0.5 \mathrm{M} \mathrm{H}_{2} \mathrm{SO}_{4}$ electrolyte in the potential range from -0.2 to $1.2 \mathrm{~V}$ (vs $\mathrm{Ag} / \mathrm{Ag} / \mathrm{Cl}$ ). Each PtNP/CNT composite ink was tested at 5, 10, 25, 50, 75, and $100 \mathrm{mV} / \mathrm{s}$ scan rates. The CVs in Figure 6a,b for both PtNP/CNT composite inks from $25 \mathrm{mM}$ and 
$100 \mathrm{mM}$ Magnus's salts show characteristic hydrogen adsorption and desorption peaks associated with the catalytic surface of platinum nanoparticles between -0.2 and $0 \mathrm{~V}$ (vs $\mathrm{Ag} / \mathrm{AgCl}$ ). The prominent reduction peak at $+0.45 \mathrm{~V}$ ( $\mathrm{vs} \mathrm{Ag} / \mathrm{AgCl}$ ) is attributed to the surface accessible catalytic crystal structure on the surface of platinum. The oxidation of $\mathrm{Pt}-\mathrm{H}$ to $\mathrm{Pt}-\mathrm{OH}$ and $\mathrm{Pt}-\mathrm{OH}$ to $\mathrm{Pt}-\mathrm{O}$ is evident from the resulting broad increase in oxidation current at $+0.96 \mathrm{~V}(\mathrm{vs} \mathrm{Ag} / \mathrm{AgCl})$ and $+1.1 \mathrm{~V}(\mathrm{vs} \mathrm{Ag} / \mathrm{AgCl})$, respectively [40]. The CV for $25 \mathrm{mM} \mathrm{PtNP} / 20 \mathrm{wt} \% \mathrm{CNT}$ (Figure S6a), $100 \mathrm{mM} \mathrm{PtNP} / 10 \mathrm{wt} \% \mathrm{CNT}$ (Figure S6b) at the lowest scan rate of $5 \mathrm{mV} / \mathrm{s}$, and both $25 \mathrm{mM}$ and $100 \mathrm{mM}$ PtNP nanocomposite inks with increasing wt \% CNTs at $25 \mathrm{mV} / \mathrm{s}$ (Figures S6c,d and S7) show the same prominent reduction and oxidation peaks with electrocatalytic activity for hydrogen on crystalline Pt.
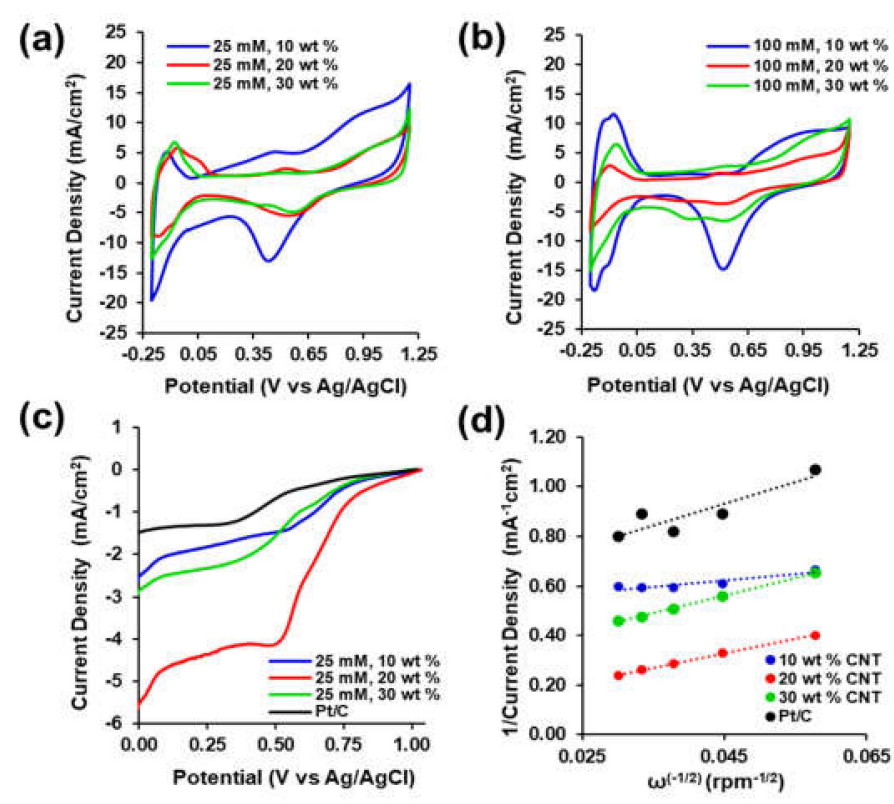

Figure 6. Electrochemical Characterization and Performance. Cyclic Voltammetry of PtNP/CNT nanocomposite inks in $0.5 \mathrm{M} \mathrm{H}_{2} \mathrm{SO}_{4}$ from $-0.2 \mathrm{~V}$ to $1.2 \mathrm{~V}$ (vs. $\mathrm{Ag} / \mathrm{AgCl}$ ) at $25 \mathrm{mV} / \mathrm{s}$ for (a) $25 \mathrm{mM} \mathrm{Pt}$ and (b) $100 \mathrm{mM}$ Pt with increasing wt\% CNTs. (c) Linear Sweep Voltammetry of inks of $25 \mathrm{mM}$ Pt with increasing $\mathrm{wt} \%$ of $\mathrm{CNTs}$ compared to $\mathrm{Pt} / \mathrm{C}$ in $0.5 \mathrm{M} \mathrm{H}_{2} \mathrm{SO}_{4}$ from $0 \mathrm{~V}$ to $1.2 \mathrm{~V}$ (vs. $\mathrm{Ag} / \mathrm{AgCl}$ ) at $10 \mathrm{mV} / \mathrm{s}$ and $1100 \mathrm{rpm}$ and (d) Koutecky-Levich Plot of $25 \mathrm{mM} \mathrm{Pt}$ with increasing wt $\% \mathrm{CNTs}$ and $\mathrm{Pt} / \mathrm{C}$ at $0.35 \mathrm{~V}$ (vs $\mathrm{Ag} / \mathrm{AgCl}$ ).

The CVs of the $25 \mathrm{mM}$ PtNP in Figure $6 \mathrm{a}$ and $100 \mathrm{mM}$ PtNP in Figure $6 \mathrm{~b}$ with $10 \mathrm{wt} \%$ of CNTs have the highest oxidation and reduction current densities between -0.2 and $0 \mathrm{~V}(\mathrm{vs} . \mathrm{Ag} / \mathrm{AgCl}$ ) from the electrochemical active surface area for the catalytic activity of hydrogen. The total charge corresponding to the catalytic activity can be evaluated from the area under the $\mathrm{CV}$ of each PtNP/CNT nanocomposite ink between -0.2 and $0 \mathrm{~V}$ (vs. $\mathrm{Ag} / \mathrm{AgCl}$ ) where the hydrogen atoms are adsorbed and desorbed. Moreover, in this same region the total charge from the double layer current from both Pt nanoparticles and CNTs is also present. The average amount of charge exchanged during the adsorption and desorption of hydrogen $\left(\mathrm{Q}_{\mathrm{H}}\right)$ and the amount of charge attributed to the non-Faradaic capacitive current from the electrochemical double layer current $\left(\mathrm{Q}_{\mathrm{ELDC}}\right)$ is evaluated from the following expression:

$$
\mathrm{Q}=\frac{1}{v_{\mathrm{b}}} \int_{\mathrm{E}_{1}}^{\mathrm{E}_{2}} \mathrm{IdE}
$$

where $Q$ is the charge in coulombs $C, v_{b}$ is the $C V$ scan rate in volts per second $(V / s), I$ is for current in amperes $(\mathrm{A})$, and $\mathrm{E}$ is the voltage in volts $(\mathrm{V})$ in the $\mathrm{CV}$ range from $-0.2 \mathrm{~V}$ to $0 \mathrm{~V}(\mathrm{vs} \mathrm{Ag} / \mathrm{AgCl})[62,63]$.

As shown in Table 1, the $25 \mathrm{mM}$ PtNP and $100 \mathrm{mM}$ with $10 \mathrm{wt} \%$ CNTs had the highest $\mathrm{Q}_{\text {ELDC }}$ with $71.2 \mathrm{mC} / \mathrm{cm}^{2}$ and $63.8 \mathrm{mC} / \mathrm{cm}^{2}$, respectively. This high charge density is due to the presence 
of a more exposed PtNP/CNT nanocomposite for ionic diffusion and double layer current through the ink structure consistent with the more open network present in the SEM images in Figure 2a and Figure S3a. The $25 \mathrm{mM}$ and $100 \mathrm{mM}$ PtNP/CNT nanocomposites also had the highest $\mathrm{I}_{\mathrm{D}} / \mathrm{I}_{\mathrm{G}}$ ratios in Figure $4 \mathrm{a}, \mathrm{b}$ indicative of a more fused $\mathrm{PtNP} / \mathrm{CNT}$ nanocomposite due to the interaction of $\mathrm{Pt}$ nanoparticles on the sidewalls of the graphitic CNTs with synergistic contribution to the higher charge density from non-Faradaic current. The QELDC of the $25 \mathrm{mM}$ PtNP with $20 \mathrm{wt} \%$ and $30 \mathrm{wt} \%$ CNTs was commensurate with the $\mathrm{Q}_{\text {ELDC }}$ of $100 \mathrm{mM}$ with $20 \mathrm{wt} \%$. However, the charge density from the electrochemical double layer of the $100 \mathrm{mM}$ PtNP with $30 \mathrm{wt} \%$ CNTs was one and a half times higher $\left(45.7 \mathrm{mC} / \mathrm{cm}^{2}\right)$ than that of the $25 \mathrm{mM}$ PtNP with $20 \mathrm{wt} \%$ and $30 \mathrm{wt} \%$ CNTs. In addition, the QELDC for the $100 \mathrm{mM}$ PtNP with 30 wt \% CNT was two times higher than with 20 wt \% CNTs. The differences in the double layer charge density can be attributed to the presence of more fused fragments of $\mathrm{Pt}$ macrotube sidewalls from $100 \mathrm{mM}$ Pt salt templates as opposed to $25 \mathrm{mM}$. The SEM images of the $100 \mathrm{mM}$ PtNP/CNT nanocomposite inks in Figure S3 show the dispersed fragments of Pt microtube sidewalls made up of smaller Pt nanoparticles fused with CNTs. As seen in Figure S3g-i, the $100 \mathrm{mM}$ PtNP with 30 wt \% CNTs has an overall more densely packed nanocomposite ink structure made up of smaller primary Pt nanoparticles dispersed in a more compact CNT network thus, increasing the overall double layer charge density in the negative potential region of the CV where catalytic activity for hydrogen occurs. In addition, the charge density from the catalytic oxidation of hydrogen $\left(\mathrm{Q}_{\mathrm{H}}\right)$ for all the PtNP/CNT nanocomposite inks was evaluated from the anodic desorption of hydrogen in the $\mathrm{CV}$ region from -0.2 to $0 \mathrm{~V}$ (vs $\mathrm{Ag} / \mathrm{AgCl}$ ).

The $100 \mathrm{mM}$ PtNP and $30 \mathrm{wt} \%$ CNT nanocomposite ink had the highest $\mathrm{Q}_{\mathrm{H}}$ of $48.9 \mathrm{mC} / \mathrm{cm}^{2}$. Meanwhile, of the remaining nanocomposite inks both the $25 \mathrm{mM}$ and $100 \mathrm{mM} \mathrm{PtNP}$ with $10 \mathrm{wt} \%$ CNTs had lower charge density for the desorption of hydrogen at $8.77 \mathrm{mC} / \mathrm{cm}^{2}$ and $9.17 \mathrm{mC} / \mathrm{cm}^{2}$, respectively. The main difference in $100 \mathrm{mM} \mathrm{PtNP}$ with $30 \mathrm{wt} \% \mathrm{CNT}$ structure is the exposure for electrolyte of the fragments consisting of the small primary $\mathrm{Pt}$ nanoparticles in the nanocomposite ink structure. The disparity in $\mathrm{Q}_{\mathrm{H}}$ amongst the PtNP/CNT nanocomposite inks could be a result of the electrolyte accessibility to the crystal surface of the Pt nanoparticles from a difference in the distribution of these nanoparticles and their aggregates throughout the CNT network.

In addition, Table 1 shows the electrochemical active surface areas correlating with the electrochemical double layer current $\left(\mathrm{ECSA}_{\mathrm{ELDC}}\right)$ and the catalytic activity of hydrogen desorption $\left(\mathrm{ECSA}_{\mathrm{H}}\right)$ are determined from the calculated $\mathrm{Q}_{\mathrm{ELDC}}$ and $\mathrm{Q}_{\mathrm{H}}$, respectively. The ECSA was evaluated using the subsequent equation $[62,63]$ :

$$
\mathrm{ECSA}=\frac{\mathrm{Q}}{\Gamma *(\mathrm{Pt} \text { Loading } \text { electrode })}
$$

where ECSA is the electrochemical active surface area in $\mathrm{cm}^{2} / \mathrm{mg}_{\mathrm{Pt}}, \mathrm{Q}$ is the charge density from the $\mathrm{CV}$ from $-0.2 \mathrm{~V}$ to $0 \mathrm{~V}$ (vs $\mathrm{Ag} / \mathrm{AgCl}$ ) in $\mathrm{mC} / \mathrm{cm}^{2}$ electrode, Pt loading is the mass of the reduced macrotubes in the PtNP/CNT nanocomposite ink on the GC electrode in $\mathrm{mg}_{\mathrm{Pt}} / \mathrm{cm}^{2}{ }_{\text {electrode, }}$, and $\Gamma$ is the charge for hydrogen adsorption/desorption on polycrystalline Pt being $210 \mu \mathrm{C} / \mathrm{cm}^{2} \mathrm{Pt}$ [62,63]. Overall, the $100 \mathrm{mM}$ PtNP nanocomposite inks had higher ECSA ELDC $_{\text {than }} 25 \mathrm{mM}$ PtNP nanocomposite inks. The $100 \mathrm{mM}$ PtNP with $30 \mathrm{wt} \%$ nanocomposite ink exhibited the highest $\mathrm{Q}_{\mathrm{H}}$ leading to the highest ECSA $_{\mathrm{H}}$. The high surface area and the $\mathrm{sp}^{2}$ hybridized network of CNTs combined with ion accessible crystalline PtNP surfaces in the nanocomposite ink allows for transport and rapid reduction of surface adsorbed protons and subsequent oxidation of the surface-bound protons to then desorb into the $\mathrm{H}_{2} \mathrm{SO}_{4}$ electrolyte. The ECSA $\mathrm{H}_{\mathrm{H}}$ of $39.7 \mathrm{~cm}^{2} / \mathrm{mg}_{\mathrm{Pt}}$ for $100 \mathrm{mM} \mathrm{PtNP} / 30 \mathrm{wt} \% \mathrm{CNT}$ nanocomposite ink is the highest achieved for catalytic activity for hydrogen in the current study. However, the $100 \mathrm{mM} \mathrm{PtNP} / 30$ wt \% CNT ink only performed with $31 \%$ of the active surface area of the reported $124.8 \mathrm{~cm}^{2} / \mathrm{mg}_{\mathrm{Pt}}$ for a Pt black-based electrocatalyst [64] and $27 \%$ of the reported $147.1 \mathrm{~cm}^{2} / \mathrm{mg}_{\mathrm{Pt}}$ for a commercial Pt/C electrocatalyst [64]. The lower $\mathrm{ECSA}_{\mathrm{H}}$ of the $25 \mathrm{mM} \mathrm{PtNP/CNT}$ and $100 \mathrm{mM} \mathrm{PtNP/CNT}$ nanocomposite 
inks is attributed to the larger salt template macrostructure [36] and traces of unreduced platinum salts in the chemical reduction process. Figure $6 \mathrm{a}, \mathrm{b}$ demonstrate the oxidation and reduction of the highest ratio of CNTs with the lowest concentration of Pt and a lower ratio of CNTs with the highest concentration of $\mathrm{Pt}$. As in the CVs in Figure 4, the strong pronounced reduction peak at approximately $+0.45 \mathrm{~V}$ (vs. $\mathrm{Ag} / \mathrm{AgCl}$ ) is from the reduction of Pt. The coupled oxidation peak at approximately $+1.2 \mathrm{~V}$ (vs. $\mathrm{Ag} / \mathrm{AgCl}$ ) is from the oxidation of Pt. As previously reported, the oxidation peak observed at $+0.45 \mathrm{~V}$ (vs Ag/ $\mathrm{AgCl}$ ) in the $\mathrm{CV}$ curves for both inks Figure $6 \mathrm{a}, \mathrm{b}$ is attributed to residual unreduced platinum salt, with the following half-cell reduction reaction of $[36,37,40]$ :

$$
\left[\mathrm{PtCl}_{6}\right]^{2-}(\mathrm{aq})+2 \mathrm{e}^{-} \rightarrow\left[\mathrm{PtCl}_{4}\right]^{2-}(\mathrm{aq})+2 \mathrm{Cl}^{-}(\mathrm{aq}), \mathrm{E}^{\circ}=+0.483 \mathrm{~V}(\mathrm{vs} \mathrm{Ag} / \mathrm{AgCl})
$$

The CVs in Figure $6 \mathrm{a}, \mathrm{b}$ of the $25 \mathrm{mM}$ and $100 \mathrm{mM}$ PtNP with increasing wt $\%$ of CNTs show the current density profile as a result of electrochemical double layer capacitance from the presence of CNTs and the redox current from Pt nanoparticles. Both $25 \mathrm{mM}$ and $100 \mathrm{mM}$ PtNP nanocomposites with $10 \mathrm{wt} \%$ CNTs exhibited higher oxidation and reduction current density throughout the potential range. The area under each CV represents the areal capacitance of each PtNP/CNT nanocomposite. As shown in Table 1, the areal capacitance $\left(\mathrm{C}_{\mathrm{a}}\right)$ from $\mathrm{CV}$ between -0.2 and $+1.2 \mathrm{~V}$ (vs Ag/AgCl) which includes both the double layer and faradaic current contributions was the highest for the PtNP/CNT nanocomposites with the lowest percent of CNTs. As shown from the SEM images in Figure 2, this could be attributed to the more dispersed and open nanocomposite structure to facilitate electrolyte diffusion. The higher the wt $\%$ of CNTs the more aggregation of particles in the ink after being dispersed. The $\mathrm{C}_{\mathrm{a}}$ values from CV was the highest for the $25 \mathrm{mM} \mathrm{PtNP} / 10 \mathrm{wt} \% \mathrm{CNT}$ and $25 \mathrm{mM} \mathrm{PtNP} / 20 \mathrm{wt} \% \mathrm{CNT}$ inks with $17.7 \mathrm{mF} / \mathrm{cm}^{2}$ and $11.3 \mathrm{mF} / \mathrm{cm}^{2}$, respectively. Compared to that of composite inks from $100 \mathrm{mM}$ $\mathrm{Pt}$, the $25 \mathrm{mM}$ PtNP inks had higher overall areal capacitance due to higher electrochemical double layer current through the electrolyte accessible $\mathrm{sp}^{2}$ hybridized graphitic CNT network. As previously shown in the Raman spectra in Figure 4a, the $25 \mathrm{mM}$ PtNP/CNT composites had less defect density for the CNTs in the composite which is an indication of a more electrolyte-accessible CNT network for the diffusion of ions. This is due to the presence of surface-accessible catalytic sites for hydrogen binding within the potential range from $-0.2(\mathrm{vs} \mathrm{Ag} / \mathrm{AgCl})$ to $0 \mathrm{~V}(\mathrm{vs} \mathrm{Ag} / \mathrm{AgCl})$. The reduction peaks are due to accessibility of adsorption sites for hydrogen gas on the crystalline surface of Pt. The peaks are a result of the oxidation of adsorbed hydrogen, reflecting the desorption of hydrogen on the crystalline surface of Pt. Moreover, the initial electrochemical durability of the $25 \mathrm{mM}$ PtNP CNT nanocomposite inks was evaluated with extending cycling experiments by performing CV for 100 cycles at $25 \mathrm{mV} / \mathrm{s}$ (Figure S8) and EIS Nyquist plot and areal capacitance vs frequency upon completion of the 100th cycle (Figure S9). The electrochemical properties of ASR, $\mathrm{Ca}, \mathrm{Q}_{\mathrm{H}}$, and $\mathrm{ECSA}_{\mathrm{H}}$ after long term duration cycling are shown in Table S2.

\subsubsection{Linear Sweep Voltammetry}

In order to investigate the electrocatalytic activity of the PtNP/CNT composite inks, LSV measurements for ORR performance were conducted in $0.5 \mathrm{M} \mathrm{H}_{2} \mathrm{SO}_{4}$ electrolyte purged and saturated with oxygen for $30 \mathrm{~min}$ before all tests and was purged for $10 \mathrm{~min}$ between each experiment. The RDE used in all LSV experiments was polished, rinsed, and dried using the same method as the GC electrode for $\mathrm{CV}$ experiments. Each PtNP/CNT nanocomposite ink was prepared on the RDE in the same manner as CV tests. LSV experiments on all nanocomposite inks were conducted at 300, 500, 700, 900, and $1100 \mathrm{rpm}$ in $\mathrm{O}_{2}$-saturated $0.5 \mathrm{M} \mathrm{H}_{2} \mathrm{SO}_{4}$ at a scan rate of $10 \mathrm{mV} / \mathrm{s}$. Each LSV experiment was conducted by performing a cathodic sweep from $+1.2 \mathrm{~V}(\mathrm{vs}$. $\mathrm{Ag} / \mathrm{AgCl}$ ) which is more positive than the onset potential for ORR towards more negative potentials and the mass transport limited current density plateau region. The ORR catalytic performance of the $25 \mathrm{mM} \mathrm{PtNP/CNT} \mathrm{nanocomposites} \mathrm{inks}$ were compared to $40 \mathrm{wt} \% \mathrm{Pt}$ Black/Graphite $(\mathrm{Pt} / \mathrm{C})$ ink. 
Figure 6c shows LSV performance of the 25 mM PtNP with 10 wt \% CNT, 20 wt \% CNT, 30 wt \% CNT composite inks against $\mathrm{Pt} / \mathrm{C}$ at $1100 \mathrm{rpm}$. The $\mathrm{Pt} / \mathrm{C}$ ink exhibited a initial gradual increase in reduction current at $+1.01 \mathrm{~V}$ (vs $\mathrm{Ag} / \mathrm{AgCl}$ ), similarly all three of the $25 \mathrm{mM}$ PtNP nanocomposite inks showed the same initial gradual increase in reduction current density but the $10 \mathrm{wt} \%$ and $20 \mathrm{wt} \%$ inks exhibited this increase at a more positive potential $+1.03 \mathrm{~V}(\mathrm{vs} \mathrm{Ag} / \mathrm{AgCl})$. There is a $20 \mathrm{mV}$ difference in the initial onset potential difference for ORR between the $25 \mathrm{mM}$ PtNP nanocomposite inks with $10 \mathrm{wt} \%$ and $20 \mathrm{wt} \% \mathrm{CNTs}$ and $\mathrm{Pt} / \mathrm{C}$ attributed to the difference in the homogeneity of the ink to enable electrolyte access to the surface catalytic sites [65-68]. As shown in the LSV in Figure 6c, the reduction current density of the $25 \mathrm{mM} \mathrm{PtNP} / 20 \mathrm{wt} \%$ CNT nanocomposite ink showed a sharp linear increase from $+0.75 \mathrm{~V}$ (vs $\mathrm{Ag} / \mathrm{AgCl}$ ) until it reaches a plateau at $+0.5 \mathrm{~V}$ (vs $\mathrm{Ag} / \mathrm{AgCl}$ ) whereas the $25 \mathrm{mM}$ $\mathrm{PtNP}$ with $10 \mathrm{wt} \%$ and $30 \mathrm{wt} \%$ exhibited a slower and gradual increase in reduction current density. The onset potential where the sharp increase in reduction current density for ORR occurs at $+0.83 \mathrm{~V}$ (vs $\mathrm{Ag} / \mathrm{AgCl}$ ) for the $25 \mathrm{mM} \mathrm{PtNP} / 10 \mathrm{wt} \% \mathrm{CNT}$, at $+0.84 \mathrm{~V}$ (vs $\mathrm{Ag} / \mathrm{AgCl}$ ) for the $25 \mathrm{mM} \mathrm{PtNP} / 30 \mathrm{wt} \%$ $\mathrm{CNT}$, and at $+0.98 \mathrm{~V}$ (vs Ag/AgCl) for the $25 \mathrm{mM} \mathrm{PtNP} / 20 \mathrm{wt} \% \mathrm{CNT}$ nanocomposite ink. The onset potential for the sharpest increase of reduction current density for ORR for the $25 \mathrm{mM} \mathrm{PtNP} / 20 \mathrm{wt} \%$ CNT nanocomposite ink was $33 \mathrm{mV}$ more positive of that of $\mathrm{Pt} / \mathrm{C}$ ink (+0.947 V vs Ag/AgCl). Overall, the $25 \mathrm{mM}$ PtNP/20 wt \% CNT nanocomposite ink exhibited the largest limiting current density for ORR amongst all the inks and had 3.5 times the limiting current density of the $\mathrm{Pt} / \mathrm{C}$ ink.

Furthermore, Tafel plots analyzing the applied potential vs the logarithm of the current density can be used to assess the kinetics for ORR and $\mathrm{O}_{2}$ adsorption mechanism onto the $25 \mathrm{mM}$ PtNP/CNT nanocomposite inks. As shown in Figure S10, the Tafel plots of the PtNP/CNT nanocomposite inks and the benchmark Pt/C ink exhibited classical Tafel behavior. After fitting the linear high potential region of the Tafel plots, the Tafel slopes of the $25 \mathrm{mM} \mathrm{PtNP} / 10 \mathrm{wt} \% \mathrm{CNT}, 25 \mathrm{mM} \mathrm{PtNP} / 20 \mathrm{wt} \% \mathrm{CNT}, 25 \mathrm{mM}$ $\mathrm{PtNP} / 30$ wt \% CNT, and Pt/C inks were determined to be $375,235,485$, and $488 \mathrm{mV} /$ decade, respectively. The lowest value of the Tafel slope was achieved in the $25 \mathrm{mM} \mathrm{PtNP} / 20 \mathrm{wt} \% \mathrm{CNT}$ nanocomposite ink and was $253 \mathrm{mV} /$ decade lower in magnitude than the synthesized Pt/C ink. The Tafel slope of the $25 \mathrm{mM} \mathrm{PtNP} / 20 \mathrm{wt} \% \mathrm{CNT}$ nanocomposite ink is the closest in agreement with that of the commercial $\mathrm{Pt} / \mathrm{C}$ catalyst of approximately $120 \mathrm{mV} /$ decade in PEM fuel cell conditions [69,70]. The differences in performance can be attributed to the overpotentials present in the PtNP/CNT inks. Moreover, the linear regions at low and high current densities observed in the corresponding Tafel studies are an indication of performance for ORR activity of the $25 \mathrm{mM}$ PtNP/CNT nanocomposite inks (Figure S11). The $25 \mathrm{mM}$ PtNP/20 wt \% CNT nanocomposite ink had a Tafel slope of the smallest in magnitude compared to the $10 \mathrm{wt} \%, 20 \mathrm{wt} \%$, and Pt/C inks due to the higher catalytic activity for ORR [71,72].

Amongst the $25 \mathrm{mM}$ PtNP/CNT nanocomposite inks, the electrochemical performance of the $25 \mathrm{mM}$ PtNP/20 wt \% CNTs in Figure 7 shows the most active performance of all the $25 \mathrm{mM}$ PtNP/CNT nanocomposite inks for ORR. The electron transfer number per oxygen molecule involved in the ORR at each of the PtNP/CNT nanocomposite inks was determined by the Koutecky-Levich (K-L) equation given below [73]:

$$
\frac{1}{\mathrm{j}}=\frac{1}{\mathrm{j}_{\mathrm{k}}}+\frac{1}{\mathrm{~B} \omega^{0.5}}
$$

where $\mathrm{j}$ is the current density, $\mathrm{j}_{\mathrm{k}}$ is the kinetic current density, and $\omega$ is the electrode rotating rate. $\mathrm{B}$ is determined from the slope of $\mathrm{K}-\mathrm{L}$ plots (Figures $6 \mathrm{~d}$ and $7 \mathrm{~d}, \mathrm{f}$ ) based on the Levich equation as follows [73]:

$$
\mathrm{B}=0.2 \mathrm{nF}\left(\mathrm{D}_{\mathrm{O}_{2}}\right)^{\frac{2}{3}} v^{\frac{-1}{6}} \mathrm{C}_{\mathrm{O}_{2}}
$$

where $\mathrm{n}$ represents the number of electrons transferred per oxygen molecule, $\mathrm{F}$ is the Faraday constant $\left(\mathrm{F}=96,485,000 \mathrm{mC} \mathrm{mol}^{-1}\right), \mathrm{D}_{\mathrm{O} 2}$ is the diffusion coefficient of $\mathrm{O}_{2}$ in $0.5 \mathrm{M} \mathrm{H}_{2} \mathrm{SO}_{4}\left(1.93 \times 10^{-5} \mathrm{~cm}^{2} \mathrm{~s}^{-1}\right)$, $v$ is the kinematic viscosity $\left(9.50 \times 10^{-3} \mathrm{~cm}^{2} \mathrm{~s}^{-1}\right)$, and $\mathrm{C}_{\mathrm{O} 2}$ is the bulk concentration of $\mathrm{O}_{2}$ $\left(1.13 \times 10^{-6} \mathrm{~mol} \mathrm{~cm}^{-3}\right)[74,75]$. The constant 0.2 is adopted when the rotation speed is expressed in rpm [76]. 
(a)
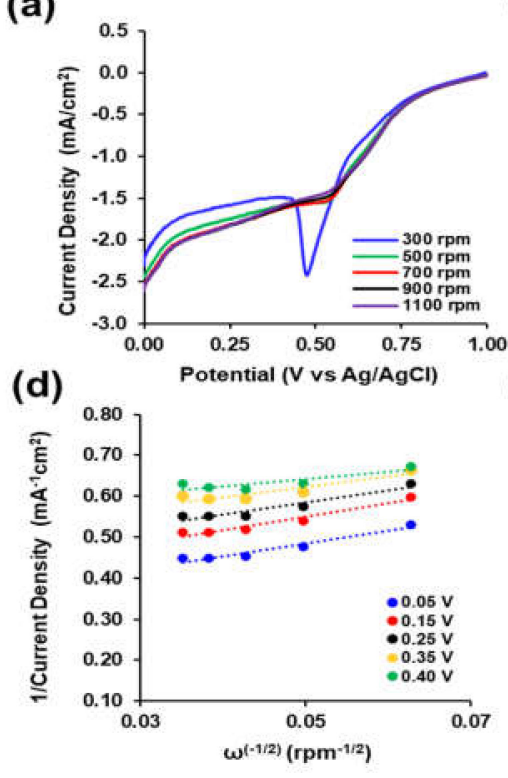

(b)
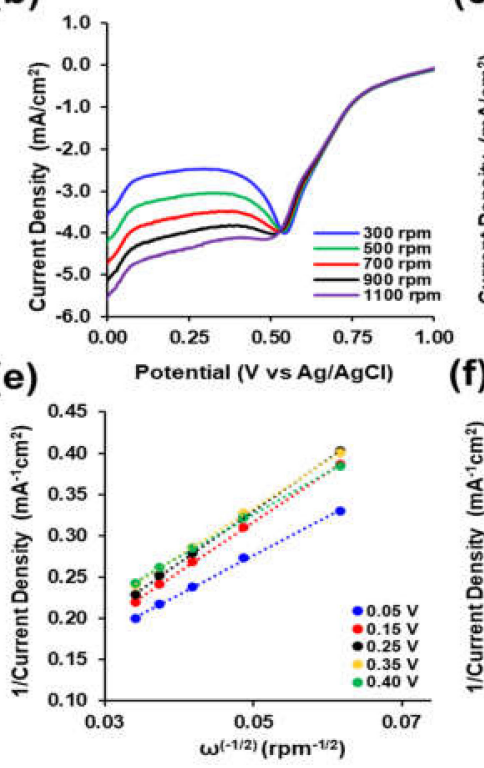

(c)
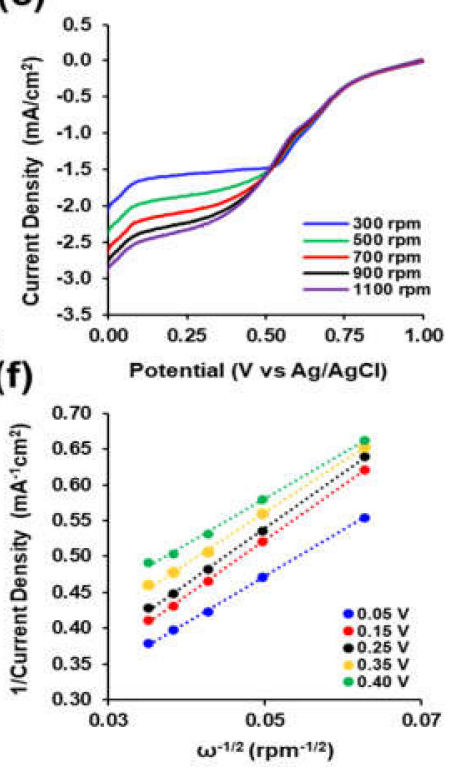

Figure 7. Electrochemical Performance. Linear Sweep Voltammetry of $25 \mathrm{mM} \mathrm{PtNP/CNT}$ nanocomposite inks at $10 \mathrm{mV} / \mathrm{s}$ in $\mathrm{O}_{2}$-saturated $0.5 \mathrm{M} \mathrm{H}_{2} \mathrm{SO}_{4}$ from $+1.0 \mathrm{~V}$ to $0 \mathrm{~V}$ (vs. $\mathrm{Ag} / \mathrm{AgCl}$ ) at 300, 500, 700, 900, and $1100 \mathrm{rpm}$ with (a) $10 \mathrm{wt} \%$ CNTs, (b) $20 \mathrm{wt} \% \mathrm{CNTs}$, and (c) $30 \mathrm{wt} \%$ CNTs. Koutecky-Levich plots of $25 \mathrm{mM}$ PtNP/CNT nanocomposite inks with (d) $10 \mathrm{wt} \%$, (e) $20 \mathrm{wt} \%$, and (f) $30 \mathrm{wt} \%$ CNTs.

Figure $7 \mathrm{a}-\mathrm{c}$ shows the LSV of the $25 \mathrm{mM} \mathrm{PtNP} / \mathrm{CNT}$ at $10 \mathrm{mV} / \mathrm{s}$ in $\mathrm{O}_{2}$ saturated $0.5 \mathrm{M} \mathrm{H}_{2} \mathrm{SO}_{4}$ electrolyte from $+1.0 \mathrm{~V}$ to $0 \mathrm{~V}$ (vs $\mathrm{Ag} / \mathrm{AgCl}$ ) at 300, 500, $700 \mathrm{rpm}, 900$, and $1100 \mathrm{rpm}$. The LSV for all three $25 \mathrm{mM}$ PtNP with increasing wt \% of CNTs shows a steady increase followed by a rapid linear increase in reduction current density until achieving the limiting current density region plateau. Figure 7a depicts the gradual steady increase in reduction current density from $+1.0 \mathrm{~V}(\mathrm{vs} \mathrm{Ag} / \mathrm{AgCl})$ until $+0.73 \mathrm{~V}$ (vs $\mathrm{Ag} / \mathrm{AgCl}$ ) before a rapid steep linear increase until $+0.55 \mathrm{~V}$ (vs $\mathrm{Ag} / \mathrm{AgCl}$ ) where it reaches another steady gradual increase until $+0.08 \mathrm{~V}$ ( $\mathrm{vs} \mathrm{Ag} / \mathrm{AgCl}$ ) followed by a sharper increase to $0 \mathrm{~V}$ (vs Ag/AgCl). In addition, the LSV for $25 \mathrm{mM}$ PtNP with $20 \mathrm{wt} \% \mathrm{CNTs}$ in Figure 7b, shows a similar slow increase in reduction current density until $+0.78 \mathrm{~V}$ (vs $\mathrm{Ag} / \mathrm{AgCl}$ ) before a sharp linear increase until $+0.6 \mathrm{~V}$ (vs Ag/AgCl) before an even more rapid increase to approximately $+0.54 \mathrm{~V}$ (vs $\mathrm{Ag} / \mathrm{AgCl}$ ) followed by a decrease in reduction current density occurs until $+0.4 \mathrm{~V}$ (vs $\mathrm{Ag} / \mathrm{AgCl})$ to ultimately achieving the limiting current density plateau region to $+0.07 \mathrm{~V}$ (vs $\mathrm{Ag} / \mathrm{AgCl}$ ) where there is a rapid increase in reduction current density until $0 \mathrm{~V}$ (vs $\mathrm{Ag} / \mathrm{AgCl}$ ). Furthermore, the LSV of the $25 \mathrm{mM}$ PtNP/CNT with $30 \mathrm{wt} \% \mathrm{CNTs}$ shown in Figure 7c shows the same slow gradual increase in reduction current density until $+0.76 \mathrm{~V}$ (vs $\mathrm{Ag} / \mathrm{AgCl}$ ) followed by a sharp linear increase in reduction current density to $+0.51 \mathrm{~V}$ (vs $\mathrm{Ag} / \mathrm{AgCl}$ ) to reach the limiting current density plateau region until, finally, there is a sharp increase in reduction current density $+0.08 \mathrm{~V}(\mathrm{vs} \mathrm{Ag} / \mathrm{AgCl})$ to $0 \mathrm{~V}(\mathrm{Ag} / \mathrm{AgCl})$. This LSV performance indicates the ability of the $25 \mathrm{mM} \mathrm{PtNP/CNT} \mathrm{as} \mathrm{a} \mathrm{catalyst} \mathrm{for} \mathrm{ORR} \mathrm{through} \mathrm{a}$ multiple electron transfer reaction. The difference in onset potential between all the nanocomposite inks is due to the catalytic ability for ORR. The onset potentials of the nanocomposite inks are $+0.805 \mathrm{~V}$ ( $\mathrm{vs} \mathrm{Ag} / \mathrm{AgCl}$ ), $+0.825 \mathrm{~V}$ (vs Ag/AgCl), and $+0.819 \mathrm{~V}$ (vs Ag/AgCl) for the $10 \mathrm{wt} \%, 20 \mathrm{wt} \%$, and $30 \mathrm{wt} \%$, respectively. This difference in the onset potentials is attributed to the morphology and dispersion of the Pt nanoparticles through the CNT network. The inks with the lower percent of CNTs reached the limiting current density plateau region phase more quickly and exhibited more prominent reduction peaks. This is due to reaction rate and accessibility of hydrogen adsorption sites on the surface of the Pt electrode consistent with the results of the CV. 
As shown in Figures $6 \mathrm{~d}$ and $7 \mathrm{~d}, \mathrm{e}$, a linear relationship between $\mathrm{j}^{-1}$ (1/current density) and $\omega^{0.5}$ was observed for all the three $25 \mathrm{mM}$ PtNP/CNT nanocomposite inks. The electron transfer numbers per $\mathrm{O}_{2}$ molecule (n) were determined from the slope of the $\mathrm{K}-\mathrm{L}$ plots at $0.35 \mathrm{~V}$ (vs $\mathrm{Ag} / \mathrm{AgCl}$ ) in Figure $6 \mathrm{~d}$ to be 1.16, 5.08, and 4.12 for the $25 \mathrm{mM}$ PtNP with $10 \mathrm{wt} \% \mathrm{CNT}, 20$ wt \% CNT, and $30 \mathrm{wt} \% \mathrm{CNT}$, respectively. The electron transfer number at the $\mathrm{Pt} / \mathrm{C}$ nanocomposite ink is close to the two-electron reduction reaction process [73,75]. Moreover, an electron transfer number of 4.12 for the $25 \mathrm{mM}$ PtNP with 30 wt \% CNT nanocomposite ink correlates with the direct four electron ORR mechanism [75]. As shown in Table 2, the electron transfer numbers that are higher than 4 at potentials below $+0.35 \mathrm{~V}$ (vs $\mathrm{Ag} / \mathrm{AgCl}$ ) for the $25 \mathrm{mM} \mathrm{PtNP} / \mathrm{CNT}$ nanocomposite ink with $10 \mathrm{wt} \% \mathrm{CNT}$ is an indication of surface passivation and the possible decrease in accessible surface catalytic sites leading to other reactions [76]. This is also consistent with the presence of pronounced reduction peaks in the LSVs in both Figure $7 \mathrm{a}, \mathrm{b}$ at approximately $+0.50 \mathrm{~V}$ (vs Ag/AgCl). The $25 \mathrm{mM} \mathrm{PtNP} / \mathrm{CNT}$ nanocomposite inks with $20 \mathrm{wt} \%$ and $30 \mathrm{wt} \%$ CNTs consisted of electron transfer numbers between 3 and 5 which is an indication that the ORR of the PtNP/CNT nanocomposite inks could likely proceed through a four-electron transfer process.

Table 2. Electron Transfer Number of 25 mM PtNP/CNT Nanocomposite Inks with varying CNT wt \%.

\begin{tabular}{crcccc}
\hline \multicolumn{5}{c}{ Electron Transfer Number (n) Per Oxygen Molecule } \\
\hline \multirow{2}{*}{$\mathbf{2 5}$ mM Platinum } & \multicolumn{4}{c}{$\mathbf{V}$ (vs Ag/AgCl) } \\
\cline { 3 - 6 } & $\mathbf{0 . 0 5} \mathbf{~ V}$ & $\mathbf{0 . 1 5} \mathbf{~ V}$ & $\mathbf{0 . 2 5} \mathbf{~ V}$ & $\mathbf{0 . 3 5} \mathbf{~}$ \\
\hline \multirow{3}{*}{$\% \mathbf{C N T}$} & $\mathbf{1 0} \mathbf{w t} \%$ & 9.49 & 8.99 & 9.68 & 1.16 \\
& $\mathbf{2 0} \mathbf{~ w t} \%$ & 6.26 & 4.88 & 4.68 & 5.08 \\
& $\mathbf{3 0} \mathbf{~ w t} \%$ & 4.55 & 3.83 & 3.80 & 4.12 \\
\hline
\end{tabular}

\section{Conclusions}

In summary, we have demonstrated the use of salt templates as sacrificial structures for the reduction and incorporation of Pt nanoparticles with CNTs to form electrocatalyst nanocomposite inks. Overall, the $100 \mathrm{mM}$ PtNP/CNT nanocomposite inks had the higher ECSA for catalytic activity for hydrogen and electrochemical double layer current. It is notable that the $100 \mathrm{mM} \mathrm{PtNP}$ nanocomposite

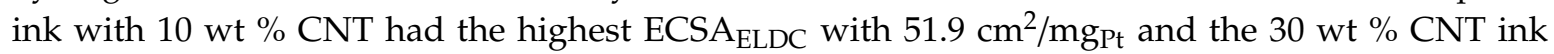
exhibited the highest overall ECSA $\mathrm{H}_{\mathrm{H}}$ with $37.9 \mathrm{~cm}^{2} / \mathrm{mg}_{\mathrm{Pt}}$. Furthermore, the $25 \mathrm{mM}$ PtNP nanocomposite inks with both $20 \mathrm{wt} \%$ and $30 \mathrm{wt} \%$ exhibited the best overall electrocatalytic activity for ORR and comparable to the synthesized $\mathrm{Pt} / \mathrm{C}$ ink electrode. The electron transfer numbers for both of the $25 \mathrm{mM}$ PtNP/CNT inks performed through a four-electron process for ORR. Moreover, the $25 \mathrm{mM}$ PtNP with $20 \mathrm{wt} \%$ CNT nanocomposite ink achieved 3.5 times the maximum limiting current density achieved by the synthesized Pt black-based Pt/C ink for ORR. The low Tafel plot slope indicates the $25 \mathrm{mM} \mathrm{PtNP} / 20 \mathrm{wt} \%$ nanocomposite ink outperformed the synthesized Pt Black-based Pt/C ink for ORR in the high potential region and was closest in magnitude to the commercial $\mathrm{Pt} / \mathrm{C}$ catalyst. In general, this all-aqueous and scalable methodology could serve a general approach for the production of electrocatalyst nanocomposite inks for the oxygen reduction reaction in a PEM fuel cell. Synthesis methods must be scalable and feasible to incorporate high surface area nanocomposites into electrocatalyst inks comprised of platinum nanoparticles with carbon nanomaterial to serve as fuel cell electrodes. To address this need, the salt template reduction approach and subsequent dispersion of the nanoparticles that make up the platinum macrotubes formed, can be applied with other carbon nanomaterials to produce various catalysts for applications beyond fuel cells. Therefore, this platform electrocatalyst composite design process of using salt templates for the rapid synthesis of noble metal nanoparticles to incorporate with carbon nanomaterials could serve as a general synthesis technique for the development of new electrocatalyst materials. 
Supplementary Materials: The following are available online at http://www.mdpi.com/2504-477X/4/4/160/s1, Figure S1. Pt nanoparticle image analysis of scanning electron microscope images, Figure S2. Scanning electron microscope images of $25 \mathrm{mM}$ Pt with $10 \mathrm{wt} \%$ CNTs, $20 \mathrm{wt} \% \mathrm{CNTs}$, and $30 \mathrm{wt} \%$ CNTs., Figure S3. Scanning electron microscopy images of $100 \mathrm{mM} \mathrm{Pt}$ with increasing wt \% of CNTs. Figure S4. X-ray diffraction spectra for $25 \mathrm{mM} \mathrm{Pt}$ and $100 \mathrm{mM}$ Pt nanocomposites with increasing $30 \mathrm{wt} \%$ of CNTs., Figure S5. Raman spectroscopy of pristine CNTs., Figure S6. Cyclic Voltammetry of PtNP/CNT Nanocomposite Inks in $\mathrm{H}_{2} \mathrm{SO}_{4}$ Electrolyte at various scan rates, Figure S7. Cyclic Voltammetry of $25 \mathrm{mM}$ Platinum and $100 \mathrm{mM}$ nanocomposite inks in $\mathrm{H}_{2} \mathrm{SO}_{4}$ Electrolyte at $25 \mathrm{mV} / \mathrm{s}$, Figure S8. Electrochemical durability by cyclic voltammetry of $25 \mathrm{mM}$ PtNP nanocomposite Inks comparing cycle 1 to cycle 100., Figure S9. Electrochemical Impedance Spectroscopy. Nyquist plots and areal capacitance vs frequency of $25 \mathrm{mM}$ PtNP Nanocomposite Inks, Figure S10. Tafel Plot for ORR of $25 \mathrm{mM}$ PtNP Nanocomposite Inks with increasing wt \% of CNTs compared to Pt/C Ink, and Figure S11. Tafel Plot for ORR of $25 \mathrm{mM}$ PtNP Nanocomposite Inks increasing CNTs in $\mathrm{O}_{2}$ purged $0.5 \mathrm{M} \mathrm{H}_{2} \mathrm{SO}_{4}$ under various rpm. Table S1. $\mathrm{Pt}$ nanoparticle range and average size of PtNP/CNT Nanocomposite Inks, Table S2. Electrochemical Properties of $25 \mathrm{mM}$ PtNP/CNT Nanocomposite Inks after 100 Cycles of CV at $25 \mathrm{mV} / \mathrm{s}$.

Author Contributions: Conceptualization, E.A.N. and F.J.B.; methodology, E.A.N.; validation, F.J.B. and D.D.C.; formal analysis, E.A.N. and F.J.B.; investigation, E.A.N., F.J.B., D.A.M., A.N.R., D.J.R., H.W.M., M.H.J. and A.N.M.; resources, E.A.N. and F.J.B.; data curation, E.A.N., F.J.B., D.A.M., A.N.R., D.J.R., H.W.M., and M.H.J.; writing—original draft preparation, E.A.N., F.J.B., D.A.M., A.N.R., and M.H.J.; writing-review and editing, E.A.N., F.J.B., D.A.M., M.H.J., and D.D.C.; visualization, E.A.N.; funding acquisition, E.A.N. All authors have read and agreed to the published version of the manuscript.

Funding: This work was supported by the US Army Combat Capabilities Development Command, Army Research Office, Physics Division, Proposal No. 74787-PH and done in collaboration with the Combat Capabilities Development Command Army Research Laboratory-Sensors and Electron Devices Directorate (CCDC ARL-SEDD).

Acknowledgments: The authors would like to thank Kirk Ingold for the support through the Photonics Research Center and Lance Richardson for assistance with instrument acquisition, maintenance, and training at the United States Military Academy West Point.

Conflicts of Interest: The authors declare no conflict of interest.

\section{References}

1. Wang, Y.; Chen, K.S.; Mishler, J.; Cho, S.C.; Adroher, X.C. A review of polymer electrolyte membrane fuel cells: Technology, applications, and needs on fundamental research. Appl. Energy 2011, 88, 981-1007. [CrossRef]

2. Liu, J.; Jiao, M.; Lu, L.; Barkholtz, H.M.; Li, Y.; Wang, Y.; Jiang, L.; Wu, Z.; Liu, D.; Zhang, L.; et al. High performance platinum single atom electrocatalyst for oxygen reduction reaction. Nat. Commun. 2017, 8, 15938. [CrossRef] [PubMed]

3. Rajala, T.; Kronberg, R.; Backhouse, R.; Buan, M.E.M.; Tripathi, M.; Zitolo, A.; Jiang, H.; Laasonen, K.; Susi, T.; Jaouen, F.; et al. A platinum nanowire electrocatalyst on single-walled carbon nanotubes to drive hydrogen evolution. Appl. Catal. B Environ. 2020, 265, 1-12. [CrossRef]

4. Sonkar, P.K.; Prakash, K.; Yadav, M.; Ganesan, V.; Sankar, M.; Gupta, R.; Yadav, D.K. Co(II)-porphyrin-decorated carbon nanotubes as catalysts for oxygen reduction reactions: An approach for fuel cell improvement. J. Mater. Chem. A 2017, 5, 6263. [CrossRef]

5. Vincent, I.; Bessarabov, D. Electrochemical Characterization and Oxygen Reduction Kinetics of Cu-incorporated Cobalt Oxide Catalyst. Int. J. Electrochem. Sci. 2016, 11, 8002-8015. [CrossRef]

6. Jahan, M.; Bao, Q.; Loh, K.P. Electrocatalytically Active Graphene-Porphyrin MOF Composite for Oxygen Reduction Reaction. J. Am. Chem. Soc. 2012, 134, 6707-6713. [CrossRef]

7. Yang, J.; Ganesan, P.; Ishihara, A.; Nakashima, N. Carbon Nanotube-based Non-precious Metal Electrode Catalysts for Fuel Cells, Water Splitting and Zinc-air Batteries. Chem. Cat. Chem. 2019, 11, 5929-5944. [CrossRef]

8. Taylor, A.D.; Kim, E.Y.; Humes, V.P.; Kizuka, J.; Thompson, L.T. Inkjet printing of carbon supported platinum 3-D catalyst layers for use in fuel cells. J. Power Sources 2007, 171, 101-106. [CrossRef]

9. Hakolal, L.; Parra Puerto, A.; Varri, A.; Maaninen, T.; Kucernak, A.; Viik, S.; Smolander, M. Anode ink formulation for a fully printed flexible fuel cell stack. Flex. Print. Electron. 2020, 5, 1-12.

10. Gupta, C.; Maheshwari, P.H.; Dhakate, S.R. Development of multiwalled carbon nanotubes platinum nanocomposite as efficient PEM fuel cell catalyst. Mater. Renew. Sustain. Energy 2016, 5, 1-11. [CrossRef]

11. Li, Y.; Zhou, W.; Wang, H.; Xie, L.; Liang, Y.; Wie, F.; Idrobo, J.C.; Pennycook, S.J.; Dai, H. An oxygen reduction electrocatalyst based on carbon nanotube-graphene complexes. Nat. Nanotechnol. 2012, 7, 394-400. [CrossRef] 
12. Li, Y.; Li, Y.; Zhu, E.; McLouth, T.; Chiu, C.-Y.; Huang, X.; Huang, Y. Stabilization of High-Performance Oxygen Reduction Reaction Pt Electrocatalyst Supported on Reduced Graphene Oxide/Carbon Black Composite. J. Am. Chem. Sec. 2012, 134, 12326-12329. [CrossRef]

13. Tang, H.; Chen, J.H.; Huang, Z.P.; Wang, D.Z.; Ren, Z.F.; Nie, L.H.; Kuang, Y.F.; Yao, S.Z. High dispersion and electrocatalytic properties of platinum on well-aligned carbon nanotube arrays. Carbon 2004, 1, 191-197. [CrossRef]

14. Tian, J.; Wu, W.; Tang, Z.; Wu, Y.; Burns, R.; Tichnell, B.; Liu, Z.; Chen, S. Oxygen Reduction Reaction and Hydrogen Evolution Reaction Catalyzed by Pd-Ru Nanoparticles Encapsulated in Porous Carbon Nanosheets. Catalysts 2018, 8, 329. [CrossRef]

15. Che, G.L.; Lakshmi, B.B.; Fisher, E.R.; Martin, C.R. Carbon nanotubule membranes for electrochemical energy storage and production. Nature 1998, 393, 346-349. [CrossRef]

16. Chai, G.S.; Yoon, S.B.; Yu, J.-S.; Choi, J.-H.; Sung, Y.-E.J. Ordered porous carbons with tunable pore sizes as catalyst supports in direct methanol fuel cell. Phys. Chem. B 2004, 108, 7074-7079. [CrossRef]

17. Bessel, C.A.; Laubernds, K.; Rodriguez, N.M.; Baker, R.T. Graphite Nanofibers as an Electrode for Fuel Cell Applications. J. Phys. Chem. B 2001, 105, 1115-1118. [CrossRef]

18. Vinodgopal, K.; Haria, M.; Meisel, D.; Kamat, P. Fullerene-Based Carbon Nanostructures for Methanol Oxidation. Nano Lett. 2004, 4, 415-418. [CrossRef]

19. Yang, R.; Qiu, X.; Zhang, H.; Zhu, W.; Wang, Z.; Huang, X.; Chen, L. Monodispersed hard carbon spherules as a catalyst support for the electrooxidation of methanol. Carbon 2005, 43, 11-16. [CrossRef]

20. Li, W.; Liang, C.; Qiu, J.; Zhou, W.; Han, H.; Wei, Z.; Sun, G.; Xin, Q. Carbon nanotubes as support for cathode catalyst of a direct methanol fuel cell. Carbon 2002, 40, 791-794. [CrossRef]

21. Cui, H.-F.; Ye, J.-S.; Zhang, W.-D.; Wang, J.; Sheu, F.-S. Electrocatalytic reduction of oxygen by a platinum nanoparticle/carbon nanotube composite electrode. J. Electroanal. Chem. 2005, 577, 295-302. [CrossRef]

22. Song, C.-H.; Park, J.-S. Effect of Dispersion Solvents in Catalyst Inks on the Performance and Durability of Catalyst Layers in Proton Exchange Membrane Fuel Cells. Energies 2019, 12, 549. [CrossRef]

23. Norskov, J.K.; Rossmeisel, J.; Logadottir, A.; Lindqvist, L.; Kitchin, J.R.; Bligaard, T.; Jonsson, H. Origin of the Overpotential for Oxygen Reduction at a Fuel-Cell Cathode. J. Phys. Chem. B. 2004, 108, 17886-17892. [CrossRef]

24. Tong, X.; Zhang, J.; Zhang, G.; Wei, Q.; Chenitz, R.; Claverie, J.R.; Sun, S. Ultrathin Carbon-Coated Pt/Carbon Nanotubes: A Highly Durable Electrocatalyst for Oxygen Reduction. Chem. Mater. 2017, 29, 9579-9587. [CrossRef]

25. Wang, R.; Dong, X.-Y.; Du, J.; Zhao, J.-Y.; Zang, S.-Q. MOF-Derived Bifunctional Cu 3 P Nanoparticles Coated by a N,P-Codoped Carbon Shell for Hydrogen Evolution and Oxygen Reduction. Adv. Mater. 2017, 30, 1703711. [CrossRef]

26. Shao, Y.; Zhang, S.; Wang, C.; Nie, Z.; Liu, J.; Wang, Y.; Lin, Y. Highly durable graphene nanoplatelets supported Pt nanocatalysts for oxygen reduction. J. Power Sources 2010, 195, 4600-4605. [CrossRef]

27. Kou, R.; Shao, Y.; Wang, D.; Engelhard, M.H.; Kwak, J.H.; Wang, J.; Viswanathan, V.V.; Wang, C.; Lin, Y.; Wang, Y.; et al. Enhanced activity and stability of Pt catalysts on functionalized graphene sheets for electrocatalytic oxygen reduction. Electrochem. Commun. 2009, 11, 954-957. [CrossRef]

28. Viva, F.A.; Bruno, M.M.; Franceschini, E.A.; Thomas, Y.R.J.; Ramos Sanchez, G.; Solorza-Feria, O.; Corti, H.R. Mesoporous carbon as Pt support for PEM fuel cell. Int. J. Hydrogen Energy 2014, 39, 8821-8826. [CrossRef]

29. Pei, K.; Banham, D.; Feng, F.; Furstenhaupt, T.; Ye, S.; Birss, V. Oxygen reduction activity dependence on the mesoporous structure of imprinted carbon supports. Electrochem. Commun. 2010, 12, 1666-1669. [CrossRef]

30. Kongkanand, A.; Kuwabata, S.; Girishkumar, G.; Kamat, P. Single-Wall Carbon Nanotubes Supported Platinum Nanoparticles with Improved Electrocatalytic Activity for Oxygen Reduction Reaction. Langmuir 2006, 22, 2392-2396. [CrossRef]

31. Zhang, S.; Yuan, X.; Hin, J.N.; Wang, H.; Friedrich, K.A.; Schulze, M. A review of platinum-based catalyst layer degradation in proton exchange membrane fuel cells. Power Sources 2009, 194, 588-600. [CrossRef] 
32. Yang, M.; Yang, Y.; Liu, Y.; Shen, G.; Yu, R. Platinum nanoparticles-doped sol-gel/carbon nanotubes composite electrochemical sensors and biosensors. Biosens. Bioelectron. 2006, 21, 1125-1131. [CrossRef]

33. Biener, J.; Wittstock, A.; Baumann, T.; Weissmuller, J.; Baumer, M.; Hamza, A.V. Surface Chemistry in Nanoscale Materials. Materials 2009, 2, 2404-2428. [CrossRef]

34. Lin, Y.; Cui, X.; Yen, C.; Wai, C.M. Platinum/Carbon Nanotube Nanocomposite Synthesized in Supercritical Fluid as Electrocatalysts for Low-Temperature Fuel Cells. J. Phys. Chem. B 2005, 109, 14410-14415. [CrossRef] [PubMed]

35. Wang, M.; Hyung, J.P.; Kabir, S.; Neyerlin, K.C.; Kariuki, N.N.; Lv, H.; Stamenkovic, V.R.; Myers, D.J.; Ulsh, M.; Mauger, S.A. Impact of Catalyst Ink Dispersing Methodology on Fuel Cell Performance Using in-Situ X-ray Scattering. ACS Appl. Energy Mater. 2019, 2, 6417-6427. [CrossRef]

36. Burpo, F.J.; Nagelli, E.A.; Winter, S.J.; McClure, J.P.; Bartolucci, S.F.; Burns, A.R.; O’Brien, S.F. Salt-Templated Hierarchically Porous Platinum Macrotube Synthesis. Chem. Sel. 2018, 3, 4542-4546. [CrossRef]

37. Burpo, F.J.; Nagelli, E.A.; McClure, J.P.; Bartolucci, S.F.; Bui, J.; Losch, A.R. Salt-templated Cu-Pt Alloy Macrotubes. Catalysts 2019, 9, 662. [CrossRef]

38. Burpo, F.J.; Nagelli, E.A.; Morris, L.A.; Woronowicz, K.; Mitropoulos, A.N. Salt-Mediated Au-Cu Nanofoam and Au-Cu-Pd Porous Macrobeam Synthesis. Molecules 2018, 23, 1701. [CrossRef]

39. Burpo, F.J.; Losch, A.R.; Nagelli, E.A.; Winter, S.J.; Bartolucci, S.F.; McClure, J.P.; Baker, D.R.; Bui, J.K.; Burns, A.R.; O'Brien, S.F.; et al. Salt-Templated Synthesis Method for Porous Platinum-based Macrobeams and Macrotubes. J. Vis. Exp. 2020, 159, e61395. [CrossRef]

40. Burpo, F.J.; Nagelli, E.A.; Bartolucci, S.F.; Mitropoulos, A.N.; McClure, J.P.; Baker, D.R.; Losch, A.R.; $\mathrm{Chu}$, D. Salt-Templated Platinum-Palladium Porous Macrobeam Synthesis. MRS Commun. 2019, 9, 280-287. [CrossRef]

41. Magnus, G. Über Einige Neue Verbindungen des Platinchlörures. Pogg. Ann. 1828, 14, 239-242.

42. Magnus, G. Ann. Chem. Phys. 1828, 2, 110. Available online: https://gallica.bnf.fr/ark:/12148/bpt6k6569192f/ f113.item (accessed on 7 October 2020).

43. Shinozaki, K.; Zack, J.W.; Pylypenko, S.; Pivovar, B.S.; Kocha, S.S. Oxygen Reduction Reaction Measurements on Platinum Electrocatalysts Utilizing Rotating Disk Electrode Technique II. Influence of Ink Formulation, Catalyst Layer Uniformity and Thickness. J. Electrochem. Soc. 2015, 162, F1384-F1396. [CrossRef]

44. Krishnamurthy, B.; Deepalochani, S. Performance of Platinum Black and Supported Platinum Catalysts in a Direct Methanol Fuel Cell. Int. J. Electrochem. Sci. 2009, 4, 386-395.

45. Rasband, W.S. Image U.S. National Institutes of Health, Bethesda, Maryland, USA. 1997-2018. Available online: https://imagej.nih.gov/ij/ (accessed on 7 October 2020).

46. Schneider, C.A.; Rasband, W.S.; Eliceiri, K.W. NIH Image to ImageJ: 25 years of image analysis. Nat. Methods 2012, 9, 671-675. [CrossRef] [PubMed]

47. Su, X.; Wu, J.; Hinds, B.J. Catalytic activity of ultrathin Pt films on aligned carbon nanotube arrays. Carbon 2011, 49, 1145-1150. [CrossRef] [PubMed]

48. Silva, R.A.; Hashimoto, T.; Thompson, G.E.; Rangel, C.M. Characterization of MEA degradation for an open air cathode PEM fuel cell. Int. J. Hydrog. 2012, 37, 7299-7308. [CrossRef]

49. Yu, Y.; Li, J.; Wang, H.J.; Yuan, X.Z.; Pan, M. A review on performance degradation of proton exchange membrane fuel cells during startup and shutdown processes: Causes, consequences and mitigation strategies. J. Power Sources 2012, 205, 10-23. [CrossRef]

50. Yuan, X.Z.; Li, H.; Zhang, S.S.; Martin, J.; Wang, H.J. A review of polymer electrolyte membrane fuel cell durability test protocols. J. Power Sources 2011, 22, 9107-9116. [CrossRef]

51. Chen, Z.W.; Waje, M.; Li, W.Z.; Yan, Y.S. Supportless Pt and PtPd Nanotubes as Electrocatalysts for Oxygen-Reduction Reactions. Angew. Chem. 2007, 119, 4138-4141. [CrossRef]

52. Malarda, L.M.; Pimentaa, M.A.; Dresselhaus, G.; Dresselhaus, M.S. Raman spectroscopy in graphene. Phys. Rep. 2009, 473, 51-87. [CrossRef]

53. Chaudhary, A.; Kumari, S.; Kumar, R.; Teotia, S.; Pratap Singh, B.; Pratap Singh, A.; Dhawan, S.K.; Dhakate, S.R. Lightweight and Easily Foldable MCMB-MWCNTs Composite Paper with Exceptional Electromagnetic Interference Shielding. ACS Appl. Mater. Interfaces 2016, 8, 10600-10608. [CrossRef] [PubMed] 
54. Kumar, R.; Dhakate, S.R.; Gupta, T.; Saini, P.; Singh, B.P.; Mathur, R.B. Effective improvement of the properties of light weight carbon foam by decoration with multi-wall carbon nanotubes. J. Mater. Chem. A 2013, 1, 5727-5735. [CrossRef]

55. Dresselhaus, M.S.; Jorio, A.; Souza Filho, A.G.; Saaito, R. Defect characterization in graphene and carbon nanotubes using Raman spectroscopy. Phil Trans. R. Soc. A 2010, 368, 5355-5377. [CrossRef] [PubMed]

56. Kang, J.; Wen, J.; Jayaramb, S.H.; Wang, X.; Chen, S. Electrochemical characterization and equivalent circuit modeling of single-walled carbon nanotube (SWCNT) coated electrodes. J. Power Sources 2013, 234, 208-216. [CrossRef]

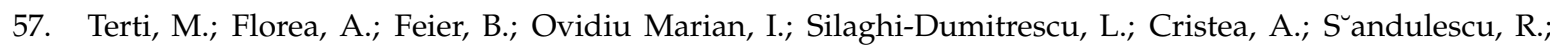
Cristea, C. Electrochemical Impedance Studies on Single and Multi-Walled Carbon Nanotubes-Polymer Nanocomposites for Biosensors Development. J. Nanosci. Nanotechnol. 2015, 15, 3385-3393. [CrossRef]

58. Zhao, S.; Li, Y.; Yin, H.; Liu, Z.; Luan, E.; Zhao, F.; Tang, Z.; Liu, S. Three-dimensional graphene/Pt nanoparticle composites as freestanding anode for enhancing performance of microbial fuel cells. Sci. Adv. 2015, 1, 1-8. [CrossRef]

59. Zhou, X.D.; Pederson, L.R.; Templeton, J.W.; Stevenson, J.W. Electrochemical Performance and Stability of the Cathode for Solid Oxide Fuel Cells, I. Cross Validation of Polarization Measurements by Impedance Spectroscopy and Current-Potential Sweep. J. Electrochem. Soc. 2010, 157, B220-B227. [CrossRef]

60. Wang, H.; Pilon, L. Reply to comments on Intrinsic limitations of impedance measurements in determining electric double layer capacitances. Electrochim. Acta 2012, 76, 529-531. [CrossRef]

61. Pandit, B.; Karade, S.S.; Sankapal, B.R. Hexagonal VS2 Anchored MWCNTs: First Approach to Design Flexible Solid-State Symmetric Supercapacitor Device. ACS Appl. Mater. Interfaces 2017, 9, 44880-44891. [CrossRef]

62. Pozio, A.; De Francesco, M.; Cemmi, A.; Cardellini, F.; Giorgi, L. Comparison of high surface Pt/C catalysts by cyclic voltammetry. J. Power Sources 2002, 105, 13-19. [CrossRef]

63. Stevens, D.A.; Dahna, J.R. Electrochemical Characterization of the Active Surface in Carbon-Supported Platinum Electrocatalysts for PEM Fuel Cells. J. Electrochem. Soc. 2003, 150, A770-A775. [CrossRef]

64. Wang, H.; Chen, Y.; Xie, W.; Han, X.; Feng, Q.; Jiang, R.; Shang, H.; Zhang, F.; Gao, L.; Wang, Z. Construction of Highly Active Pt/Ni-Fe Layered Double Hydroxide Electrocatalyst towards Methanol Oxidation in Alkaline Medium. Int. J. Electrochem. Sci. 2019, 14, 7961-7972. [CrossRef]

65. Gojkovi, S.L.; Zecevic, S.K.; Savinell, R.F. $\mathrm{O}_{2}$ Reduction on an Ink-Type Rotating Disk Electrode Using Pt Supported on High-Area Carbons. J. Electrochem. Soc. 1998, 145, 3713-3720. [CrossRef]

66. Shinozaki, K.; Zack, J.W.; Pylypenka, S.; Richards, R.M.; Pivovar, B.S.; Kocha, S.S. Benchmarking the oxygen reduction reaction activity of Pt-based catalysts using standardized rotating disk electrode methods. Int. J. Hydrog. 2015, 40, 16820-16830. [CrossRef]

67. Xu, Y.; Chen, C.; Zhou, M.; FU, G.; Zhao, Y.; Chen, Y. Improved oxygen reduction activity of carbon nanotubes and graphene through adenine functionalization. RSC Adv. 2017, 7, 26722-26728. [CrossRef]

68. Zhang, J.; Xia, Z.; Dai, L. Carbon-based electrocatalysts for advances energy conversion and storage. Sci. Adv. 2015, 1, 1-19. [CrossRef]

69. Conway, B.E.; Tilak, B.V. Interfacial processes involving electrocatalytic evolution and oxidation of $\mathrm{H} 2$, and the role of chemisorbed H. Electrochim. Acta 2002, 47, 3571-3594. [CrossRef]

70. Sheng, W.; Gasteiger, H.A.; Shao-Horn, Y. Hydrogen oxidation and evolution reaction kinetics on platinum: Acid vs alkaline electrolytes. J. Electrochem. Soc. 2010, 157, B1529-B1536. [CrossRef]

71. Wakabayashi, N.; Takeichi, M.; Itagaki, M.; Uchida, H.; Watanabe, M. Temperature-dependence of oxygen reduction activity at a platinum electrode in an acidic electrolyte solution investigated with a channel flow double electrode. J. Electroanal. Chem. 2005, 574, 339-346. [CrossRef]

72. Halseid, R.; Bystron, T.; Tunold, R. Oxygen reduction on platinum in aqueous sulphuric acid in the presence of ammonium. Electrochim. Acta 2006, 51, 2737-2742. [CrossRef]

73. Wang, S.; Yu, D.; Dai, L. Polyelectrolyte functionalized carbon nanotubes as efficient metal-free electrocatalysts for oxygen reduction. J. Am. Chem. Soc. 2011, 133, 5182-5185. [CrossRef] [PubMed]

74. El-Deab, M.S.; Ohsaka, T. Hydrodynamic voltammetric studies of the oxygen reduction at gold nanoparticles-electrodeposited gold electrodes. Electrochim. Acta 2002, 47, 4255-4261. [CrossRef] 
75. Chen, G.; Yang, H.Y. Electrochemical study of oxygen reduction reaction on natural chalcopyrite in sulfuric acid and ferric solutions. Int. J. Electrochem. Sci. 2016, 11, 34-44.

76. Demarconnay, L.; Coutanceau, C.; Léger, J.-M. Study of the oxygen electroreduction at nanostructured PtBi catalysts in alkaline medium. Electrochim. Acta 2008, 53, 3232-3241. [CrossRef]

Publisher's Note: MDPI stays neutral with regard to jurisdictional claims in published maps and institutional affiliations.

(C) 2020 by the authors. Licensee MDPI, Basel, Switzerland. This article is an open access article distributed under the terms and conditions of the Creative Commons Attribution (CC BY) license (http://creativecommons.org/licenses/by/4.0/). 